Florida International University FIU Digital Commons

$11-8-2011$

\title{
The Effects of Dynamic Culturing Environments on Cell Populations Relevant to Heart Valve Tissue Engineering
}

Catalina Martinez

Florida International University, martinez.12@gmail.com

DOI: $10.25148 /$ etd.FI11120611

Follow this and additional works at: https://digitalcommons.fiu.edu/etd

\section{Recommended Citation}

Martinez, Catalina, "The Effects of Dynamic Culturing Environments on Cell Populations Relevant to Heart Valve Tissue Engineering" (2011). FIU Electronic Theses and Dissertations. 505.

https://digitalcommons.fiu.edu/etd/505 


\title{
FLORIDA INTERNATIONAL UNIVERSITY
}

\author{
Miami, Florida
}

\section{THE EFFECTS OF DYNAMIC CULTURING ENVIRONMENTS ON CELL POPULATIONS RELEVANT TO HEART VALVE TISSUE ENGINEERING}

\author{
A thesis submitted in partial fulfillment of the \\ requirements for the degree of \\ MASTER OF SCIENCE \\ in \\ BIOMEDICAL ENGINEERING \\ by
}

Catalina Martinez 
To: Dean Amir Mirmiran

College of Engineering and Computing

This thesis, written by Catalina Martinez, and entitled The Effects of Dynamic Culturing Environments on Cell Populations Relevant to Heart Valve Tissue Engineering, having been approved in respect to style and intellectual content, is referred to you for judgment.

We have read this thesis and recommend that it be approved.

Yei-Chih Huang

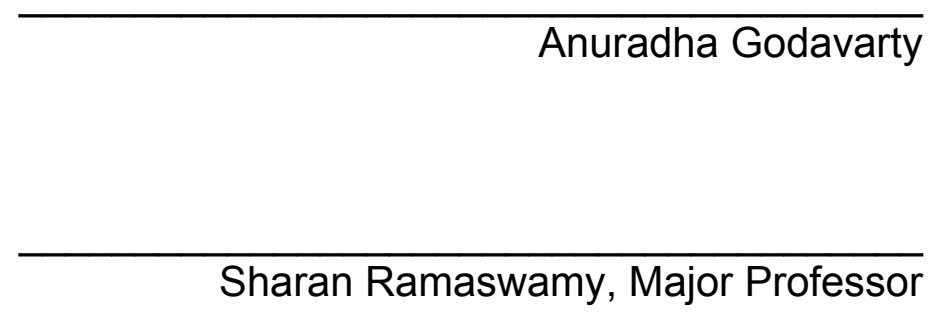

Date of Defense: November 8, 2011

The thesis of Catalina Martinez is approved.

$\begin{array}{r}\text { Dean Amir Mirmiran } \\ \text { College of Engineering and Computing } \\ \hline \begin{array}{r}\text { Dean Lakshmi N. Reddi } \\ \text { University Graduate School }\end{array}\end{array}$

Florida International University, 2011 


\section{DEDICATION}

This work is dedicated to my parents Alfredo Martinez and Yamileth Cano, as well as my brother Juan Pablo Martinez who have always been a source of love and inspiration for me. 


\section{ACKNOWLEDGMENTS}

First of all I would like to thank my research mentor Dr. Sharan Ramaswamy for guiding me throughout the process of my research findings. Without his insights, support and experience in the field, it would have been impossible for me to complete this research thesis. I am very thankful for all the pieces of advice, which always encourage me to follow through my experiments.

I would also like to thank the members of my thesis committee Dr. Yen-Chi Huang and Dr. Anuradha Godavarty for their time and support. I specially would like to thank Dr. Huang for allowing me to use his laboratory.

Lastly I want to thank Angela Henao, Stephanie Van Gulden and Natasha Fernandez for helping me run experiments, and to the rest of my lab thank you for being there, working next to me in a healthy and nice environment. 


\title{
ABSTRACT OF THE THESIS \\ THE EFFECTS OF DYNAMIC CULTURING ENVIRONMENTS ON CELL POPULATIONS RELEVANT TO HEART VALVE TISSUE ENGINEERING
}

\author{
by \\ Catalina Martinez \\ Florida International University, 2011 \\ Miami, Florida \\ Professor Sharan Ramaswamy, Major Professor
}

The design of a tissue engineered pulmonary valve (TEPV) involves cells source(s), scaffold, in vitro conditioning system and the functional stability of the TEPV in vivo. Vascular cells (pulmonary artery smooth muscle (SMCs) and endothelial cells (ECs)) and periodontal ligament derived stem cells (PDLSCs) are relevant sources for the designing of TEPVs. In this study, labeling of these cell populations with super paramagnetic iron oxide microparticles along with concomitant usage of transfection agents was followed by visualization using magnetic resonance, while Intracellular iron oxide was confirmed by prussian blue staining and fluorescence microscopy. Also, the potential of PDLSC as a feasible source for TEPVs was investigated, expressing differentiative capacity to both SMC and EC phenotypes by a combination of biochemical and mechanical stimulation. Flow conditioning in a u-shaped bioreactor augmented collagen production in SMC-EC $(99.5 \%$ for $n=3)$ and PDLSC (93.3\% for $n=3)$ seeded scaffolds after a 3-week culturing period $(P<0.05)$. 


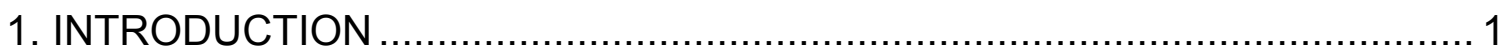

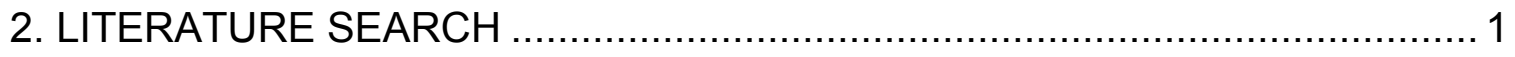

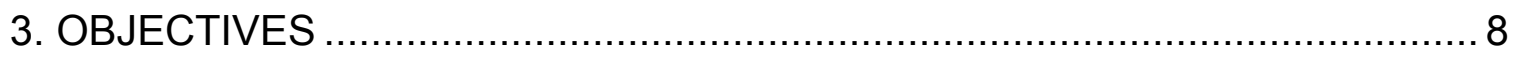

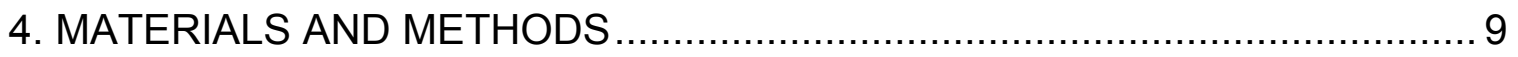

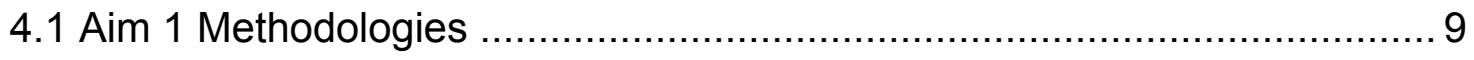

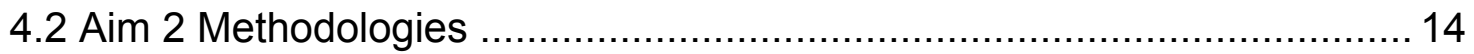

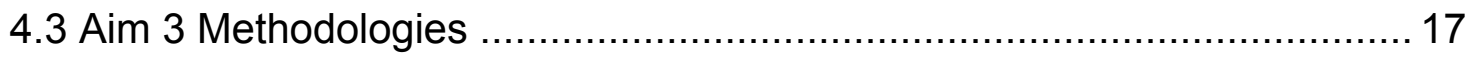

5. RESULTS AND DISCUSSION PART I: SPIO MICROPARTICLE LABELING STUDIES FOR THREE DIFFERENT CELL POPULATIONS, IMPLICATIONS FOR TISSUE ENGINEERED HEART VALVES ….................. 22

6. RESULTS AND DISCUSSION PART II: PDLSC AS A POTENTIAL CELL SOURCE FOR HEART VALVE TISSUE ENGINEERING ..................... 32

7. RESULTS AND DISCUSSION PART III: VASCULAR CELL MIGRATORY ACTIVITY UNDER DYNAMIC STATES COMPARED TO STATIC CONTROLS BY SPIO-LABELED CELLS ….................................... 40

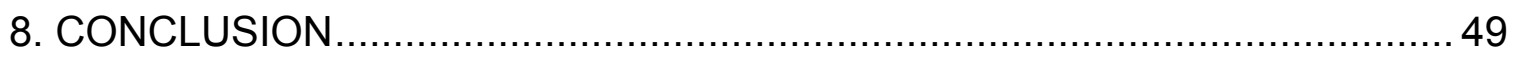

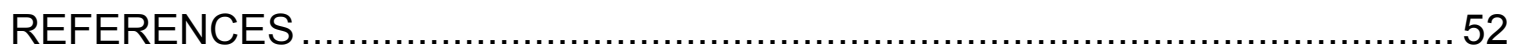




\section{LIST OF FIGURES}

FIGURE

PAGE

Figure 1: U-shaped bioreactor for in-vitro conditioning of TEPV's.

Figure 2: (A-B) A cMR image of the SMCs with a $200 \mu \mathrm{g} / \mathrm{mL}$ concentration of the SPIO particles. (A) Under 24 hours incubation time. (B) Under 48 hours incubation time. (C-D) A cMR image of the ECs under a 24 hours incubation time. (C) With a $100 \mu \mathrm{g} / \mathrm{mL}$ concentration of the SPIO particles. (D) With a $200 \mu \mathrm{g} / \mathrm{mL}$ concentration of the SPIO particles. (E) A cMR image of the PDLSCs with a $200 \mu \mathrm{g} / \mathrm{mL}$ concentration of the SPIO particles under 24 hours incubation time.

Figure 3: Proliferation of human vascular cells SMC (green) and EC (red) unlabeled, and SPIO-labeled at three different concentrations: 50 , 100 and $200 \mathrm{ug} / \mathrm{m}$ in a 48 hour incubation time. The values for both cell types at the different cell concentration did not have any significant differences (N.S) based on the independent t-test.

Figure 4: Viability of human vascular cells SMC (green) and EC (red) unlabeled, and SPIO-labeled at three different concentrations: 50, 100 and $200 \mathrm{ug} / \mathrm{m}$ in a 48 hour incubation time. The values for both cell types at the different cell concentration did not have any significant differences (N.S) based on the independent t-test.

Figure 5: Proliferation for PDLSC's unlabeled and SPIO-labeled at a concentration of $200 \mathrm{ug} / \mathrm{ml}$. There were no statistical differences in the values based on the independent t-test.

Figure 6: Viability for PDLSC's unlabeled and SPIO-labeled at a concentration of $200 \mathrm{ug} / \mathrm{ml}$. There were no statistical differences in the values based on the independent t-test.

Figure 7: Prussian Blue Stain taken at 100X. Scale bar $=200 \mu \mathrm{m}$. Blue dots represent the iron, while the cytoplasm is shown in a light pink color.

(A) SMC's, (B) EC's and (C) PDLSC's cell populations.

Figure 8: Immunofluorescence of SMC's taken at 100X, Scale bar=200 $\mu \mathrm{m}$ (Left) and 200X, Scale bar $=100 \mu \mathrm{m}$ (Right). Both images were stained for F-actin (green), DAPI (blue) and the fluorescence from the Bangs particles (red).

Figure 9: Immunofluorescence of EC taken at 100X, Scale bar $=200 \mu \mathrm{m}$ (Left) and 400X, Scale bar $=100 \mu \mathrm{m}$ (Right). Both images were stained 
for F-actin (green), DAPI (blue) and the fluorescence from the Bangs particles (red).

Figure 10: Immunofluorescence of PDLSC taken at 100X, Scale bar $=200 \mu \mathrm{m}$ (Left) and 200X, Scale bar $=50 \mu \mathrm{m}$ (Right). Both images were stained for F-actin (green), DAPI (blue) and the fluorescence from the Bangs particles (red).

Figure 11: Quantitative RT-PCR of SMC unlabeled (2) and labeled with SPIO microparticles (2). Each column is normalized by GAPDH (endogenous gene). Values for all genes were not statistically different.

Figure 12: Quantitative RT-PCR of EC unlabeled (5) and labeled with SPIO microparticles (5). Each column is normalized by GAPDH. Values for all genes were not statistically different with exception of PECAM 1 and Tie $1(P<0.05)$.

Figure 13: Quantitative RT-PCR of PDLSC unlabeled (5) and labeled with SPIO microparticles (5). Each column is normalized by GAPDH. Values for all genes were not statistically different with exception of Sox 2 and Slug $(P<0.05)$.

Figure 14: Quantitative RT-PCR of PDLSC. Group 1: Cells cultured in regular basal medium. Group 2: Cells cultured in differentiating media. Group 3: Cell cultured in basal medium and exposed to $1 \mathrm{dyne} / \mathrm{cm}^{2}$. Group 4: Cells cultured in differentiating media and exposed to 1 dyne $/ \mathrm{cm}^{2}$. Each column is normalized by GAPDH.

Figure 15: $(A$ and $B)$ represents staining for alpha-sma for cells from group 1: negative staining $(A)$ and group 2: positive staining $(B)$, while Figure $9(C$ and $D)$ represents staining for $v W F$ for cells from group 1: negative staining (A) and group 2: positive staining (B). DAPI (Blue) marks the nucleus of the cells, while Texas Red (Red) marks either alpha-sma ( $A$ and $C$ ) or VWF ( $B$ and $D)$. The images were taken at 20X, on an upright fluorescent microscope.

Figure 16: $(A$ and $C)$ represents positive staining for alpha-sma for cells from group $3(A)$ and group $4(B)$, while Figure 10(B and D) represents positive staining for VWF for cells from group $3(A)$ and group 4 (B). DAPI (Blue) marks the nucleus of the cells, while Texas Red (Red) marks either alpha-sma ( $A$ and $C$ ) or vWF ( $B$ and $D)$. The images were taken at 20X, on an inverted fluorescent microscope.

Figure 17: (A) represents positive staining to alpha-sma for mooth muscle cells, while (B) represents positive staining for VWF for endothelial cells. DAPI (Blue) marks the nucleus of the cells, while Texas Red (Red) marks either alpha-sma (A) or VWF (B). The images were taken at 20X, on an upright fluorescent microscope. 
Figure 18: MRI of PDLSC-seeded scaffolds in situ within the U-shaped bioreactor. The figure shows axial and sagittal slices from T2*weighted images. Dark spots within the scaffold region are cells, which are hypointense due signal attenuation caused by the intracellular SPIO micro-particles.

Figure 19: H\&E staining for general tissue assessment and organization of PDLSCs 2 weeks of culturing (A): Cultured under static conditions (B): Cultured under flow conditions. Magnification is $20 \mathrm{x}$.

Figure 20: Immunofluorescence of PDLSC seeded scaffold (A) Cultured under static conditions (B) Cultured under flow conditions. Magnification is $20 \mathrm{x}$.

Figure 21: DNA content of SMC-EC seeded scaffolds after 3 weeks of incubation. Values presented are the mean of the measurements for 3 samples. Error bars indicate standard error.

Figure 22: Composition content of SMC-EC seeded scaffolds after 3 weeks of incubation. Values presented are the mean of the measurements for 3 samples. Error bars indicate standard error. Insignificant comparisons are designated by "N.S.". The group exposed to flow exhibited a $99.5 \%$ increase in collagen compared to the static group $(p<0.05)$.

Figure 23: DNA content of PDLSC seeded scaffolds after 3 weeks of incubation. Values presented are the mean of the measurements for 3 samples. Error bars indicate standard error.

Figure 24: Composition content of PDLSC seeded scaffolds after 3 weeks of incubation. Values presented are the mean of the measurements for 3 samples. Error bars indicate standard error. Insignificant comparisons are designated by "N.S.". The group exposed to flow exhibited a $93.3 \%$ increase in collagen compared to the static group $(p<0.05)$. 


\section{LIST OF TABLES}

TABLE

PAGE

Table 1: qRT-PCR Primer Sequences.

Table 2: P-value for GAPDH gene expression within the four groups.

Error! Bookmark not defined.

Table 3: P-value for Beta-Integrin gene expression within the four groups. Error! Bookmark not defined.

Table 4: P-value for THY-1 gene expression within the four groups. . Error! Bookmark not defined.

Table 5: P-value for PECAM-1 gene expression within the four groups.

Error! Bookmark not defined.

Table 6: P-value for FLK-1 gene expression within the four groups... Error! Bookmark not defined.

Table 7: P-value for VE-CADHERIN gene expression within the four groups....................................................................

Table 8: Gene expression comparison among all groups Error! Bookmark not defined.

Table 9: Percentage Increase of Gene Expression per Group Compared to Group 1 .......................................Error! Bookmark not defined. 


\section{INTRODUCTION}

There are over 25,000 infants born with congenital heart anomalies in the US alone (www.congenitalheartdefects.com), which usually demand either replacement of the pulmonary valve (PV) and/or reconstruction of the right ventricular outflow tract (RVOT). Available PV replacements in the market are: mechanical, xenograft fixed-tissue, and homograft valves. Prosthetic heart valves are implanted in approximately 275,000 patients yearly (1). However, current prosthetic heart valves have several limitations. Mechanical valves are prone to thrombosis; therefore life-long anticoagulant therapy is required (2). Xenograft fixed-tissue, commonly referred to as bioprosthetic heart valves do not require anticoagulants, but they have limited durability and are prone to calcification (3). Homograft valves are limited in availability and often experience immune rejection (4). Overall, none of these valve replacement strategies offer potential for growth, and are hence particularly limited for pediatric patients, as they will require multiple operations during their development. $(1,5-7)$.

\section{LITERATURE SEARCH}

2.1 Heart Valve Disease (HVD) - Heart Valve disease (HVD) results from the malfunctioning of one or more heart valves and is affected by factors such as immune reaction, trauma, inheritance and environmental factors (diet, smoking, etc.). The main job of heart valves is to open and close in a synchronized manner allowing blood to flow in one direction and preventing back flow. A significant amount of HVD is characterized by valve stenosis, causing the valve to become narrow, therefore affecting hemodynamics by decreasing the cross sectional 
area for blood to flow. Similarly, improper valve closure causes regurgitation, creating a backflow of blood into the heart. In this study, we are specifically concerned with the pulmonary valve (PV), which lies between the right ventricle and the pulmonary artery and has three cusps responsible for blood flow from the heart to the lungs, as well as the exchange of oxygen and carbon dioxide. Malfunction of a PV demands a replacement by currently available designs.

2.2 PV Replacements - The actual PV replacements available are mechanical, bioprosthetic or homograft valves. Mechanical heart valves (MHVs) are generally built from of titanium or pyrolytic carbon; their first designs include the caged ball, tilting disk and bileaflet versions (2). Bioprostheric heart valves (BHVs) are native valves usually derived from bovine or porcine sources, which undergo a fixative chemical process before implantation in the human body $(6,7)$. All of these replacements are beneficial for the patient; yet they have serious limitations. For example, MHVs are durable, but are thrombogenic, require lifelong anticoagulants, and therefore are more prone to infection (2). BHVs do not require anticoagulants, but do not last as long as MHVs as they undergo calcification on their leaflets (3). Homograft valves on the other hand, contain some viable cells which would permit some tissue remodeling activity; however as they are allografts, the often experience immunological rejection.

2.3 Tissue Engineered Heart Valves (TEHV) - Tissue engineering applies principles of engineering and life sciences toward the development of biological substitutes. This approach utilizes a bioabsorbable scaffolding material, seeded with cells and grown in vitro, to ultimately produce functional living tissue 
which can be implanted in the body (8). The extracellular matrix (ECM) formed by the autologous cells provides the basic framework for the tissue and it is also responsible for its mechanical and structural properties. Cells organize, grow, proliferate and produce native ECM on the scaffold's temporary matrix. In theory, due to their ability to permit somatic growth, the creation of a tissue-engineered structure from autologous cells can potentially offer several advantages over currently available treatment options $(1,4,8)$. Additionally, tissue engineered pulmonary heart valves (TEPVs) would have fewer supply limitations in comparison with homografts. The Mayer group (9) found promising results, creating PV leaflets and sections of the main pulmonary artery. These structures were found to be non-thrombogenic and promote tissue remodeling. However, they had limited durability in the order of months (9). Sutherland et al. constructed TEHVs by seeding bone marrow derived stem cells (BMSC) onto nonwoven scaffolds that functioned in the pulmonary outflow tract of sheep for 8 months (8). While the results from these studies are clearly encouraging, the current critical step for TEHV research is to identify a clinically viable autologous cell source, a scaffold with the suitable mechanical and biodegradable properties, an optimized in vitro conditioning system, and a way to track the functional stability of the tissue engineering implant in vivo in order to successfully move forward from in vitro conditioning into in vivo studies, and subsequently to clinical trials (10).

2.4 Cell Sources for Tissue Engineered Pulmonary Valves - Three relevant cell sources pertinent in tissue engineered hear valve efforts include 
human vascular cells (native pulmonary artery smooth muscle (SMCs) and endothelial cells (ECs)) and stem cell sources. Vascular cells (SMCs and ECs) have shown to promote heart valve tissue formation $(1,9,11)$. Therefore, these vascular cells need to be assessed in order to track tissue remodeling in vivo. Studies using bone marrow derived stem cells (BMSCs) which are readily accessible, have shown that after a TEPV has been implanted, the BMSCs exhibit some pluripotency for potential vascularization of bioengineered tissues (8). Evidence of smooth muscle cell phenotype has been obtained by Sutherland et al. (8) by expressing vimentin, and alpha-smooth muscle actin (alpha-SMA) markers in his studies. However they could not detect evidence of endothelial cell phenotype.

Human periodontal ligament derived stem cells (PDLSCs) on the other hand, are a readily available source of pluripotent stem cells that may potentially support the valve phenotype. They are derived from the cranial neural crest and recent studies by Huang et al. (12) have shown that PDLSCs are a population of multipotent stem cells that can be differentiated into neural and mesenchymal lineages. Sub-populations of PDLSCs contain 4 embryonic stem cell markers (Oct4, Nanog, Sox2, Klf4) and exhibit the potential to differentiate to neurogenic, cardiomyogenic, osteogenic and chondrogenic cell lineages (12). Therefore, PDLSCs have the potential to promote concomitant differentiation into the EC and SMC phenotypes (12-14).

2.5 Scaffold Material for Tissue Engineered Pulmonary Valves - The scaffold material serves as a support structure capable of retaining cells and 
engineered tissue formation. Scaffold materials must allow cell attachment and migration, enable diffusion of cell nutrient and expressed products, as well as possess mechanical and biological properties to provide structural support. TEPVs are usually constructed by seeding cells onto porous synthetic of natural scaffolds (5). Natural scaffolds, from decellularized valve tissue already have proper anatomical structure, intrinsic bioactivity and desired mechanical properties (5). However, their innate variability, limited supply, and potential immunogenic reaction are obstacles in the field.

On the other hand, synthetic scaffolds offer the added benefit of design flexibility, in which their material and structural properties, as well as anatomical shape can be tailored to meet the functional necessities $(15,16)$. Polyesters such as polyglycolic acid (PGA) and poly--latic acid (PLLA) are the most widely used scaffold materials in the field of TEPVs. These materials mixed together in a 50:50 blend create an immunogenic scaffold capable of degrading by hydrolysis into naturally occurring metabolites $(15,16)$. This scaffold has an approximate fiber diameter of $0.012-0.015 \mathrm{~mm}$ and a density of $61.75 \mathrm{mg} / \mathrm{ml}$. Its benefits include a high porosity factor (>97\%) allowing for a high cell seeding density. The PGA/PLLA scaffold has already been successful demonstrating its ability to rapidly grow cells and form an organized 3D tissue structure $(1,5)$.

2.6 In Vitro Conditioning Systems - Mechanical stimulation of engineered tissue growth in vitro can be achieved with a bioreactor, which has shown to improve the physical integrity of engineered heart valves prior to implantation $(9,16,17)$. The mechanical environment would potentially include a 
physiological flow and pressure for conditioning the developing valve tissue construct in a sterile setting prior to in vivo implantation (17-19). Different bioreactors have been designed by researchers to promote tissue formation and valve phenotype (5,9,16-19). Hoerstrup et al (17) developed an in vitro cell culture system that provided the developing valve constructs with physiological pressure and flow to develop adequate strength of the constructs prior to implantation. In a similar manner, Sticker et al (18) conducted a study to compare tissue samples exposed to stretch versus normal conditions showing there is higher tissue production on samples treated mechanically, i.e exposed to cyclic flexure. Engelmayr et al (5) showed that laminar flow combined with cyclic flexure in a flow-stretch-flex (FSF) bioreactor allowed for larger tissue formation when compared to laminar flow without cyclic flexure when seeding BMSCs in a non-woven scaffold material (PGA/PLLA). However, Engelmayr this study did not use physiological levels, as the shear stresses were very low. The effects of fluid shear stresses on engineered tissue growth levels (i.e. collagen) can be evaluated in terms of bulk protein levels, differentiation potential, mechanical properties, gene expression and cell signaling events.

The device utilized in our study, is an u-shaped bioreactor capable of replicating physiological hemodynamic conditions during in vitro tissue development, while keeping laminar conditions as shown by precise steady state states. This is a key advantage over other bioreactor designs incapable of generating physiologically relevant stresses, which have been widely recognized as an essential aspect of engineered heart valve tissue formation $(5,16)$. 


\subsection{Noninvasive Visualization of Functional TEPV's - A cell-tracking}

agent is required to be safe to use, i.e., does not alter cell activity, and permits retention within the cell for a reasonable period to allow for visualization over longitudinal time points (20). One approach would be to label the cells with super paramagnetic iron oxide (SPIO) microparticles and visualize the resulting artifacts as regions of signal voids characterized using magnetic resonance imaging (MRI). Other cell tracking methods include labeling with green fluorescent protein (GFP). However, this method is harmful for the tissue, as it may interfere with the protein synthesis of the cells and does not provide sufficient resolution beyond that of subcutaneous tissue, which is needed for the heart valve application (21). Another cell tracking method involves gadolinium compounds, which create contrast through T1 images, however the main disadvantage of this contrast agent lies on its low sensitivity (22). On the other hand, SPIO microparticles have already been demonstrated to work for MRI investigations without harming the cell (23-26). For example, Terrovitis et al. (24) showed that labeling BMSCs with ferumoxides was not toxic to the cells, and the cells could further be visualized in collagen gels/scaffolds. Ko et al. (27) showed that cellular MRI methodologies could further be used to visualize an implanted scaffold and the cellular behavior around the scaffold in the mouse model.

MRI has been reported to be useful in monitoring TEPV growth and function in vivo (20). MRI allows cell detection utilizing SPIO microparticles as the contrast agent by accelerated $\mathrm{T} 2^{*}$ decay, which will present as hypointense regions caused by the intracellular iron oxide particles (10). This visualization is 
necessary from the beginning of the in vitro culturing period of the engineered construct and could in theory be progressively tracked, even after implantation (8, 28-30).

To understand a process where there are many unknowns, such as the cell migration that will occur on the scaffold region, we propose to use SPIO and cellular MRI. These include the migration of cells within and outside of a scaffold region, as well as the potential migration of native cells into the scaffold from regions proximal to the site of the implant. The ability to observe the type of cells that would adhere/migrate longitudinally and preferentially in/out of the scaffold material is a key aspect in predicting the quality and quantity of tissue that would form. On the other hand, efforts to label and track PDLSCs, a potential cell source in heart valve tissue engineering has to date not been performed.

\section{OBJECTIVES}

Our objectives were to conduct an in-depth study of the longitudinal position and migration patterns of cells during the engineered heart valve tissue development process under static and dynamic environments. This would be achieved through SPIO cell labeling and subsequent tracking studies by MRI. In addition, we wanted to investigate the potential of PDLSCs as a single, feasible source for heart valve tissue engineering. These hypothesis are addressed by the following specific aims:

3.1 Specific Aim 1: Acquire longitudinal MRI images of SPIO-labeled cell populations in engineered valve tissue in cell culture with maximum possible cell contrast without compromising cell viability, proliferation and 
differentiative capacity - Specifically, we wish to augment iron oxide uptake in human vascular cells (native pulmonary artery smooth muscle (SMCs), endothelial cells (ECs)) and label human periodontal ligament derived stem cells (PDLSCs) from currently used protocols without compromising cellular viability and without affecting cell phenotypes.

\subsection{Specific Aim 2: Differentiate PDLSC into concomitant EC and} SMC through use of a growth factor cocktail, mechanical stimulation or both - PDLSCs would be differentiated into ECs and SMCs in cell culture with growth factors, and/or would be mechanically stimulated under steady flow using shear stress at $1 \mathrm{dyne} / \mathrm{cm}^{2}$ to promote further differentiation that is supportive of the heart valve phenotype.

\subsection{Specific Aim 3: Perform biological studies of the SPIO-labeled} cells in 3D static or dynamic polymer seeded scaffolds determine extracellular matrix (ECM) production and changes in cell phenotype - Cellseeded polymers would be housed in a bioreactor and exposed to fluid induced shear stress conditioning. Vascular cell migratory activity under dynamic states would be compared to static controls by means of SPIO as the contrast agent.

\section{MATERIALS AND METHODS}

\subsection{Aim 1 Methodologies}

Cell Labeling: Various concentrations of Bangs particles (Bangs laboratories, Fishers, IN), which are co-labeled with a fluorescent red tag (excitation $=660 \mathrm{~nm}$, emission $=690 \mathrm{~nm}$ ) were used to label the vascular cells 
(Genlantis, Fisher Scientific, IN) at two different incubation times (24 hours and 48 hours), while the PDLSCs (University of Miami, Tissue Engineering Laboratory, Miami, FL) were labeled at an incubation time period of 24 hours. After proliferating all cell lineages, roughly, 3 million cells and were re-plated equally into 15 chamber slides (Fisher Scientific, PA). Vascular cells $(n=5)$ were labeled for a 24 hour period with three different concentrations of SPIO microparticles $(0.23 \mathrm{~g}$ of $\mathrm{Fe}$ per $\mathrm{ml}$ of solution: 50,100 and $200 \mu \mathrm{g} / \mathrm{ml}$ ). Concomitantly, during the same 24 hour period, cells were exposed to $4.5 \mu \mathrm{g} / \mathrm{ml}$ of a transfection agent (Protamine Sulfate, Sigma, MO). A second group of the vascular cells were labeled with ferumoxides in the same manner except that the incubation time was doubled, i.e., 48 hours. On the contrary, the PDLSCs were labeled following the protocol used by Suzuki et al. (31) for embryonic stem cells. The PDLSCs $(n=5)$ were labeled with SPIO microparticles at a concentration of $200 \mu \mathrm{g} / \mathrm{ml}$ for 24 hours. During this 24-hour period, the PDLSC's were also exposed to a $12 \mu \mathrm{g} / \mathrm{ml}$ of the transfection agent (Protamine Sulfate, Sigma, MO).

MR Imaging of Cells in Culture: For vascular cells (SMC and EC), MRI datasets were collected on a 4.7-Tesla $(200 \mathrm{MHz}) 40-\mathrm{cm}$ bore magnet with a Bruker Avance $^{\mathrm{TM}}$ (Bruker Inc., Rheinstetten, Germany) console using an actively shielded gradient set. A linear birdcage radio frequency (RF) coil with a diameter of $35 \mathrm{~mm}$ was used for imaging the samples in order to increase sensitivity of signal detection. A 2D gradient echo fast imaging (GEFI) pulse sequence with $180 \mathrm{~mm}$ resolution and $10 \mathrm{~ms}$ time of echo (TE) was employed to visualize the labeled vascular cells in the chamber slide. On the other hand, for PDLSC, MRI 
datasets were collected on a $3.0-$ Tesla $(123 \mathrm{MHz}) 60-\mathrm{cm}$ bore magnet with a Magnetom Trio, (Tim, Simens) console using an actively shielded gradient set. A transmit/receive 15 channel knee coil that provides high resolution. A 3D gradient echo pulse sequence with $60 \mathrm{~mm}$ resolution and $11.2 \mathrm{~ms}$ TE and $100 \mathrm{~ms}$ relaxation time (TR) was employed to visualize the labeled PDSLCs in the chamber slide.

Proliferation and Viability: SPIO-labeled and unlabeled cells (EC, SMC and PDLSC) were cultured for 1 week to assess proliferation and viability. EC's were cultured using Genlantis medium (Genlantis, San Diego, CA) while SMCs and PDLSC's were grown in-vitro using Dulbecco's Modified Eagle's Medium (DMEM, Lonza, Basel, Switzerland) with $4.5 \mathrm{~g} / \mathrm{l}$ glucose and I-glutamine (Invitrogen, Carlsbad, CA) supplemented with $10 \%$ fetal bovine serum (FBS, ATCC, Manasas, VA), and 1\% penicillin/streptomycin (Invitrogen, Carlasbad, CA). At both the beginning and end of 1 week, live cells were manually counted using a hemocytometer. Dead cells were excluded by addition of Trypan Blue dye (Sigma Aldrich, St. Louis, MO) prior to the counting process.

Iron Oxide Detection: After culturing SPIO-labeled and unlabeled cells (SMC, EC and PDLSC) for a week, they were rinsed with $0.01 \mathrm{M}$ Phosphate Buffered Saline (PBS) and detached from the T-75 $\mathrm{cm}^{2}$ flask (Fisher Scientific, PA) by $0.25 \%$ Trypsin-EDTA (ATCC, Manasas, VA). Cell pellets were collected in a $15 \mathrm{ml}$ conical tube (Fisher Scientific, PA) and transferred to chamber slides ( $n=6$ per cell type). After the cells attached overnight, they were fixed with $10 \%$ formalin for further detection of iron oxide. Prussian Blue Stain: Slides ( $n=3$ per 
cell type) were then incubated in a $1: 1$ working solution of $2 \%$ Potassium Ferrocyanide and $2 \%$ Hydrochloride acid for 20 min at $55^{\circ} \mathrm{C}$, washed in tap water followed by a counterstain of nuclear fast red for $5 \mathrm{~min}$. The slides were then dehydrated through alcohol, and cleared in xylene. After mounting the slides with Permount (Fisher Scientific, PA) they were examined under an upright microscope for presence of iron particles inside the cells. Fluorescent red tag in Bangs Particles: Slides ( $n=3$ per cell type) were counterstained for filamentousactin (F-actin, Invitrogen, Carlsbad, CA) using Alexa Fluor 488 conjugated phallotoxin at $5 \mathrm{U} / \mathrm{mL}$ for $20 \mathrm{~min}$ at $26^{\circ} \mathrm{C}$, and washed in PBS. The slides were then mounted and stained for DAPI with Vectashield Mounting Media (Invitrogen, Carlsbad, CA)) and examined under an inverted fluorescent microscope for presence of the red tag contained in the magnetic core of the Bangs particles (660 excitation, 690 emission).

RNA Isolation and Reverse Transcription: The cells (SMC, EC and PDLSC) were rinsed with PBS and detached from the $T-75 \mathrm{~cm}^{2}$ flask (Fisher Scientific, PA) by $0.25 \%$ Trypsin-EDTA (ATCC, Manasas, VA). Cell pellets were collected in a $15 \mathrm{ml}$ conical tube (Fisher Scientific, PA). The pellet was transferred to a $1.5 \mathrm{ml}$ RNAase free tube to perform the RNA isolation procedure. Total mRNA was purified with SV Total RNA Isolation System (Promega, Madison, $\mathrm{WI}) .1 \mu \mathrm{g}$ of total mRNA was used for reverse transcription reaction with GoScript $^{\mathrm{TM}}$ Reverse Transcription System (Promega, Madison, WI). The cDNA was synthesized using oligo (dT) 15 primer, according to the manufacturer's instructions. 
qRT-PCR for SMC, EC and PDLSC Marker Genes: Quantitative RTPCR was performed using GoTaq® qPCR Master Mix (Promega, Madison, WI). Signals were detected with a Step One Real-Time PCR System (Applied Biosystems, Carlsbad, CA). The PCR tube contains 2 primers and SYBR® green I dye reagent along with the cDNA, a product of reverse transcription mentioned above. The primers were designed to amplify the target sequence. The PCR primer sequences for SMC, EC and PDLSC are listed in Table 1. The sample tube was held at $95^{\circ} \mathrm{C}, 2$ minutes before the cycle started to activate the Taq polymerase. The cycling parameters were $95^{\circ} \mathrm{C}, 5$ seconds; $60^{\circ} \mathrm{C}, 45$ seconds; $95^{\circ} \mathrm{C}, 15$ seconds.

Table 1: qRT-PCR Primer Sequences

\begin{tabular}{|l|l|l|l|} 
& Fonward primer (5'-3') & Rever se primer (5'-3') & Size \\
\hline SMC Genes: & & & \\
\hline$\beta$-1 Integrin & CCTACTTCTGCACGATGTGATG & CCTTTGCTACGGTTGGTTACATT & $128 \mathrm{bp}$ \\
Thy-1 & TCGCTCTCCTGCTAACAGTCT & CTCGTACTGGATGGGTGAACT & $134 \mathrm{bp}$ \\
Desmin & TGAGACCATCGCGGCTAAGA & GTGTCGGTATTCCATCATCTCC & $136 \mathrm{bp}$ \\
Smoothelin & CCCTGGCATCCAAGCGTT & CTCCACATCGTTCATGGACTC & $137 \mathrm{bp}$ \\
\hline EC Genes: & & & \\
\hline PECAM1 1 & CCAAGGTGGGATCGTGAGG & TCGGAAGGATAAAACGCGGTC & $187 \mathrm{bp}$ \\
Flk-1 & GGCCCAATAATCAGAGTGGCA & CCAGTGTCATTTCCGATCACTTT & $109 \mathrm{bp}$ \\
Tie-1 & TCGAGCGGCATCTACAGTG & GCACGATGAGCCGAAAGAAG & $73 \mathrm{bp}$ \\
Tie-2 & CCCTACCTCTTGTATCTGATGCT & GCTGGTTCATTAAGGCTTCAAAG & $111 \mathrm{bp}$ \\
VE-Cadherin & GATCAAGTCAAGCGTGAGTCG & AGCCTCTCAATGGCGAACAC & $114 \mathrm{bp}$ \\
HPRT & ACCAGTCAACAGGGGACATAA & CTTCGTGGGGTCCTTTTCACC & $190 \mathrm{bp}$ \\
\hline PDLSC Genes: & & & \\
\hline Oct-4 & CTCCTGAAGCAGAAGAGGATCAC & CTTCTGGCGCCGGTTACAGAACCA & $401 \mathrm{bp}$ \\
Sox-2 & TGCAGTACAACTCCATGACCA & GTGCTGGGACATGTGAAGTCT & $278 \mathrm{bp}$ \\
Nanog & GTCTTCTGCTGAGATGC & AGTGTTTTCTGCCACC & $353 \mathrm{bp}$ \\
KIf-4 & ACGATCGTGGCCCCGGAAAAGGAC & TGATTGTAGTGCTTTCTGGTGGGCTCC & $397 \mathrm{bp}$ \\
Nestin & GCCCTGACCACTCCAGTTTA & GGAGTCCTGGATTTCCTTCC & $200 \mathrm{bp}$ \\
Slug & TGCTACACAGCAGCCAGATTCC & TTTCTGGGCTGGCCAAACAT & $383 \mathrm{bp}$ \\
P75 & CTGCAAGCAGAACAAGCAAG & GGCCTCATGGGTAAAGGAGT & $310 \mathrm{bp}$ \\
Sox-10 & TCTTGTAGTGGGCCTGGATGG & TGAACGCCTCATGGTGTGG & $303 \mathrm{bp}$ \\
\hline
\end{tabular}




\subsection{Aim 2 Methodologies}

Cell Differentiation: After PDLSCs reached 100\% confluency, they were separated into 4 groups during a week period at a cell density of $1 * 10^{6}$ cells $/ \mathrm{cm}^{2}$. Group [1] - Negative control: This group contained PDLSCs cultured in its basal media. Group [2] - Differentiating Media: This group contained PDLSCs exposed to a special media believed to induce SMCs and ECs differentiation. Group [3] BioFlux: This group of PDLSCs was subjected to a physiologically relevant shear flow $\left(1 \mathrm{dyne} / \mathrm{cm}^{2}\right.$ ) while being cultured in the Bioflux200 system (Fluxion, San Francisco, CA). Group [4] - Differentiating Media + BioFlux: This group combined the special media and the physiological relevant shear flow $\left(1 \mathrm{dyne} / \mathrm{cm}^{2}\right)$ while culturing the PDLSC inside the Bioflux200 system (Fluxion, San Francisco, CA). As positive control, both human vascular EC and SMC were utilized. [1] Negative control: This group contained PDLSCs cultured in its basal media. [2] Differentiating Media: This group contained PDLSCs exposed to a special media believed to induce SMCs and ECs differentiation. [3] BioFlux: This group of

PDLSCs was subjected to a physiologically relevant shear flow $\left(1 \mathrm{dyne} / \mathrm{cm}^{2}\right)$ while being cultured in the Bioflux200 system (Fluxion, San Francisco, CA). [4] Differentiating Media + BioFlux: This group combined the special media and the physiological relevant shear flow $\left(1 \mathrm{dyne} / \mathrm{cm}^{2}\right)$ while culturing the PDLSCs inside the Bioflux200 system (Fluxion, San Francisco, CA). As positive control, both human vascular EC and SMC were utilized.

Differentiating Media: The cocktail mix utilized to culture cells in groups [2] and [4] was hypothesized to induce differentiation of PDLSCs into EC and 
SMC concomitantly as a similar version of the mix has already been effective in differentiating PDLSCs into cardiomyocytes (32). Therefore, since PDLSCs can be differentiated into other cardiovascular cell lineages, such as cardiomyocytes, it serves to argue that they have the potential to become vascular SMCs and/or ECs $(33,34)$. The cocktail mix we have utilized contains DMEM High glucose (Invitrogen, Carlsbald, CA), 10\% fetal bovine serum (ATCC, Manasas, VA), 1\% Penicillin/streptomycin (ATCC, Manasas, VA), as well as $10 \mathrm{ng} / \mathrm{mL}$ of vascular endothelial growth factor (VEGF, BD Science, USA), $25 \mathrm{ng} / \mathrm{mL}$ of basic fibroblast growth factor (bFGF, Invitrogen, Carlsbald, CA), 10ng/mL of Insulin-like Growth Factor (IGF-1, Invitrogen, Carlsbald, CA), 10uM of 5-azacytidine (Sigma Aldrigh, St. Louis, MO), 100nM Ascorbic Acid (Sigma Aldrich, St. Louis, MO), 10nM Oxytocin (Sigma Aldrigh, St. Louis, MO), 10nM hydrogen peroxide (Sigma Aldrich, St. Louis, MO). The cocktail mix was changed every two days during a 1-week period, with exception of the hydrogen peroxide, which was added daily.

Bioflux 200 System: This system enables the user to prepare 8 cell assays in parallel, while controlling their temperature. Its interface connects an electropneumatic pump to the well plates, which initiates the "controlled shear flow". BioFlux 200 can also be connected to an inverted regular or fluorescent microscope; allowing the user to for example, perform immunohistochemical findings while the cells are being stimulated. Therefore, this system is highly conducive for assessing stem cell differentiation outcomes.

Cell Phenotype: After the 1-week period of culturing the cells under the differentiating media, cells from the four separate groups were subjected to PCR 
and immunohistochemistry in order to check for SMC and EC cell phenotypes. RNA isolation, reverse transcription and qRT-PCR methods were performed in a similar manner to that of the labeled cells as described earlier for the SPIOlabeling studies.

Immunohistochemistry: Characterization of cell phenotype by immunohistochemistry was performed. After the 1-week culture period, cells from all groups were rinsed with PBS and detached from the T-75 $\mathrm{cm}^{2}$ flasks (Fisher Scientific, PA) by Trypsin-EDTA (ATCC, Manasas, VA). Cell pellets were collected in a $15 \mathrm{ml}$ conical tube (Fisher Scientific, PA) and transferred evenly to chamber slides ( $n=6$ per group) at a density of 200,000 per chamber slide. After 24 hours, the slides were fixed in $10 \%$ buffered formalin. Sections were then washed in PBS-T $3 \times 5 \mathrm{~min}$. The sections were incubated for 1 hour in Normal Donkey Serum (1:10 in PBS-T). Next, the sections were incubated (Overnight, $\left.4^{\circ} \mathrm{C}\right)$ with mouse alpha-smooth muscle actin (1:500, Sigma Aldrich, St. Louis, MO) or rabbit von Willebrand Factor (vWF, 1:500, Invitrogen, Carlsbad, CA). After washing in PBS, the sections were incubated in their secondary antibodies for two hours Texas Red (1:800) anti-mouse IgG and Texas Red (1:400) antirabbit IgG, to identify anti-alpha-sma or anti-vWF respectively. The sections were washed again with PBS 3x5min. Finally, the slides were mounted and stained for DAPI with Vectashield Mounting Media (Invitrogen, Carlsbad, CA)) and examined under an inverted fluorescent microscope. 


\subsection{Aim 3 Methodologies}

Cell Labeling: PDLSC's were labeled with Bangs particles (Bangs laboratories, Fishers, IN), co-labeled with a fluorescent red tag (excitation $=660 \mathrm{~nm}$, emission $=690 \mathrm{~nm}$ ) at a concentration of $200 \mathrm{ug} / \mathrm{mL}$. SMCs and ECs were labeled in a similar manner as previously described. However, the Bangs particles utilized to label the SMCs were colabeled with a green tag (excitation $=480$, emission $=520$ ) while the $E C s$ were labeled with the Bang's particles colabeled with the red tag (excitation $=660 \mathrm{~nm}$, emission $=690 \mathrm{~nm}$ ) in order to distinguish the cell type under a fluorescent microscopy.

Cell Seeding: A non-woven 50:50 blend of polyglycolic acid (PGA) and poly-L-lactic acid (PLLA) scaffold (Biofelt, Concordia Fiber, RI) was utilized for cell seeding. This scaffold has an approximate fiber diameter of $0.012-0.015 \mathrm{~mm}$ and its density is $61.75 \mathrm{mg} / \mathrm{ml}$. Its benefits include its high porosity factor (>97\%). The PGA/PLLA scaffold has already been successful demonstrating its ability to rapidly grow cells and form an organized 3D tissue structure $(1,5)$. Rectangular scaffold samples $(n=12)$ of dimensions $(17 \mathrm{~mm} \times 6 \mathrm{~mm} \times 1 \mathrm{~mm})$ were subjected to Ethylene Oxide gas sterilization (AN 306, Anprolene, Andersen Products Inc., Haw River, NC) for 12 hours. After the sterilization period, each sample was placed in a hybridization tube and seeded with previously SPIO labeled and unlabeled SMC $(\sim 87 \%)-$ EC $(\sim 13 \%)$ at a density of $2 \times 10^{6}$ million cells per $\mathrm{cm}^{2}$. The hybridization tubes $(\mathrm{n}=2)$ were then placed on a rotisserie (Fisher Scientific, PA) and rotated at 8rpm inside a standard cell culture incubator operating at 
$37^{\circ} \mathrm{C}$ and $5 \% \mathrm{CO}_{2}$ for one day+ 7 days (static culture). The SPIO-labeled and unlabeled PDLSC-plated scaffolds were seeded in the PGA/PLLA scaffold in a similar manner.

Monitoring tissue development process: The mechanical conditioning for the seeded scaffolds was developed in a u-shaped bioreactor shown on Figure 1. This bioreactor is capable of replicating physiological hemodynamic

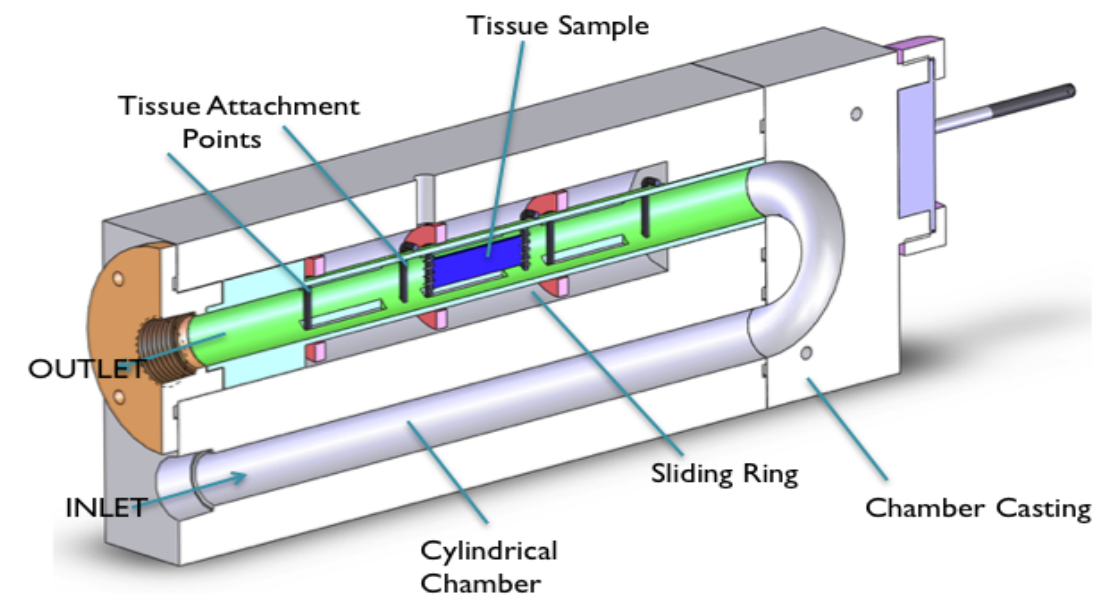

Figure 1: The u-shaped bioreactor for in vitro mechanical conditioning.

conditions during in-vitro tissue development, which has been widely recognized to be an essential aspect of engineered heart valve tissue formation $(5,16)$. Poststatic culturing of the scaffolds $(n=12)$ during a total of 8 days in the rotisserie, they were separated into two groups: static and flow. Scaffolds $(n=6)$ were then then cultured also for a two week period in dynamic conditions, housed in the ushaped bioreactor being exposed to a physiologically relevant continuous flow rate $(750 \mathrm{~mL} / \mathrm{min})$ which develops a shear stress of a $5-6$ dynes $/ \mathrm{cm}^{2}(18)$. The tissue formation studies were based on the SMC-EC-seeded-scaffolds, as well as the PDLSC seeded scaffolds. 
MRI of PDLSC-seeded Scaffold Inside Bioreactor: MRI datasets were collected on a $3.0-$ Tesla $(123 \mathrm{MHz}) 60-\mathrm{cm}$ bore magnet with a Magnetom Trio, (Tim, Simens) console using an actively shielded gradient set. A transmit/receive 15 channel knee coil that provides high resolution. A 3D gradient echo pulse sequence with $60 \mathrm{~mm}$ resolution and $11.2 \mathrm{~ms}$ TE and $100 \mathrm{~ms}$ relaxation time (TR) was employed to visualize the labeled PDSLC-seeded scaffold inside the bioreactor.

Histology: SPIO-labeled PDLSC-seeded scaffolds were fixed and embedded with paraffin at different time points for the samples exposed to flow or static conditions. While the samples cultured under static conditions were fixed and embedded in paraffin at: 1-week post static culture, 2-weeks post static culture and 3-weeks post static culture. Samples ( $n=2$ at each time point/group) were washed in PBS, and fixed in 10\% formalin, then embedded in paraffin and sectioned at 10um. Sections were stained with hematoxylin and eosin for overall morphology.

Fluorescence Validation: In order to see the migratory activity of PDLSC in the PGA/PLLA copolymer; and to validate the presence of iron through the fluorescent tag of the Bang's particles, sections were mounted and stained for DAPI with Vectashield Mounting Media (Invitrogen, Carlsbad, CA)) and examined under an inverted fluorescent microscope.

DNA Quantification: DNA was quantified after the 3 week by a technique adapted from Ramaswamy et al. (35). For each assay, thin samples (8x7X1 mm) 
were cut from PDLSC/SMC-EC seeded scaffolds (controls, and scaffolds exposed to flow) along their long axis and weighed prior to extraction. Each sample was then placed in a microcentrifuge tube and extracted in $1 \mathrm{ml}$ of 0.125 $\mathrm{mg} / \mathrm{ml}$ papain solution for 10 hours in a $600 \mathrm{C}$ water bath. The $0.125 \mathrm{mg} / \mathrm{ml}$ papain solution must made immediately prior to use by adding I-cysteine dihydrochloride (Sigma Aldrich, St. Louis, MO) to a phosphate buffered EDTA solution (PBE, Sigma Aldrich, St. Louis, MO) to a concentration of $10 \mathrm{mM}$, adding papain (minimum 10 units $/ \mathrm{mg}$ (P4762); Sigma) to a concentration of $0.125 \mathrm{mg} / \mathrm{ml}$. The PBE solution was made beforehand by adding sodium phosphate dibasic (Sigma) and Ethylenediaminetetraacetic acid (EDTA; Sigma Aldrich, St. Louis, MO) to deionized water at concentrations of 100 and $10 \mathrm{mM}$, respectively. The PBE solution needs to be balanced to $\mathrm{pH} 6.5$ with $0.5 \mathrm{~N}$ hydrochloric acid (Sigma Aldrich, St. Louis, MO) and sterile filtered using a vacuum filtration unit $(0.2 \mathrm{~mm}$ PES membrane; Nalgene Labware). The extracts were then assayed using the PicoGreen dsDNA quantitation kit (Invitrogen, Carlsbad, CA) as per the manufacturer's instructions and using a Genesys 20 spectrophotometer (Thermo Spectronic, Rochester, NY).

Extracellular Matrix Quantification: Collagen and sulfated glycosaminoglycans (S-GAG) were assayed following a similar technique used by Ramaswamy et al. (35). For the collagen assay, thin samples $(8 \times 7 \times 1 \mathrm{~mm})$ were cut from PDLSC/SMC-EC seeded scaffolds (controls, and scaffolds exposed to flow) along their long axis and weighed prior to extraction. Total collagen was extracted from samples using a solution of $0.5 \mathrm{M}$ acetic acid (Sigma 
Aldrich) and pepsin ((1 mg/ml), Sigma Aldrich, St. Louis, MO). Each sample was the placed in a microcentrifuge tube and incubated in $1 \mathrm{ml}$ of extraction solution on a rocker table ((Orbitron Rotator); Boekel Scientific, Feasterville, PA) at $4^{\circ} \mathrm{C}$ for 16 hours. For the S-GAG assay, the same extract used for the DNA assay was utilized. Subsequent to the extraction procedure, the collagen and S-GAG extracts were assayed following the protocols of the manufacturer's provided by Sircol and Blyscan assay kits. (Biocolor Ltd. Newtownabbey, N. Ireland) using a Genesys 20 spectrophotometer (Thermo Spectronic, Rochester, NY).

\subsection{Statistical Analysis}

Statistical analysis was performed utilizing the SPSS Software Version 16.0 for the independent t-test for all proliferation and viability tests $(n=5)$, as well as gene expression tests $(n=3)$ from Aim 1. For Aim 2, four different groups of cells were compared; in addition we used ANOVA through MATLAB 7.12 to be able to compare the three groups pairwise ( 1 to 2,1 to 3,1 to 4 , etc), so the probability of an incorrect result would be: $1-(0.95 \times 0.95 \times 0.95)=14.3 \%$ in order to prevent type I and type II errors. Finally, SPSS Software Version 16.0 was also utilized for performing statistical analysis for extracellular matrix and DNA quantification results $(n=3$, replicates $=5)$ from Aim 3 . 


\section{RESULTS AND DISCUSSION PART I: SPIO MICROPARTICLE}

LABELING STUDIES FOR THREE DIFFERENT CELL POPULATIONS, IMPLICATIONS FOR TISSUE ENGINEERED HEART VALVES

MR Imaging of Cells in Culture: We determined that vascular cells exposed to a concentration of $200 \mu \mathrm{g} / \mathrm{ml}$ of SPIO microparticles and incubated for a period 48 hours was optimum for detection by MRI (Figure 2). Similarly, PDLSCs were successfully imaged when exposed to a SPIO concentration of $200 \mu \mathrm{g} / \mathrm{ml}$ and incubated for a period of 24 hours (Figure $2 \mathrm{e})(36,37)$.
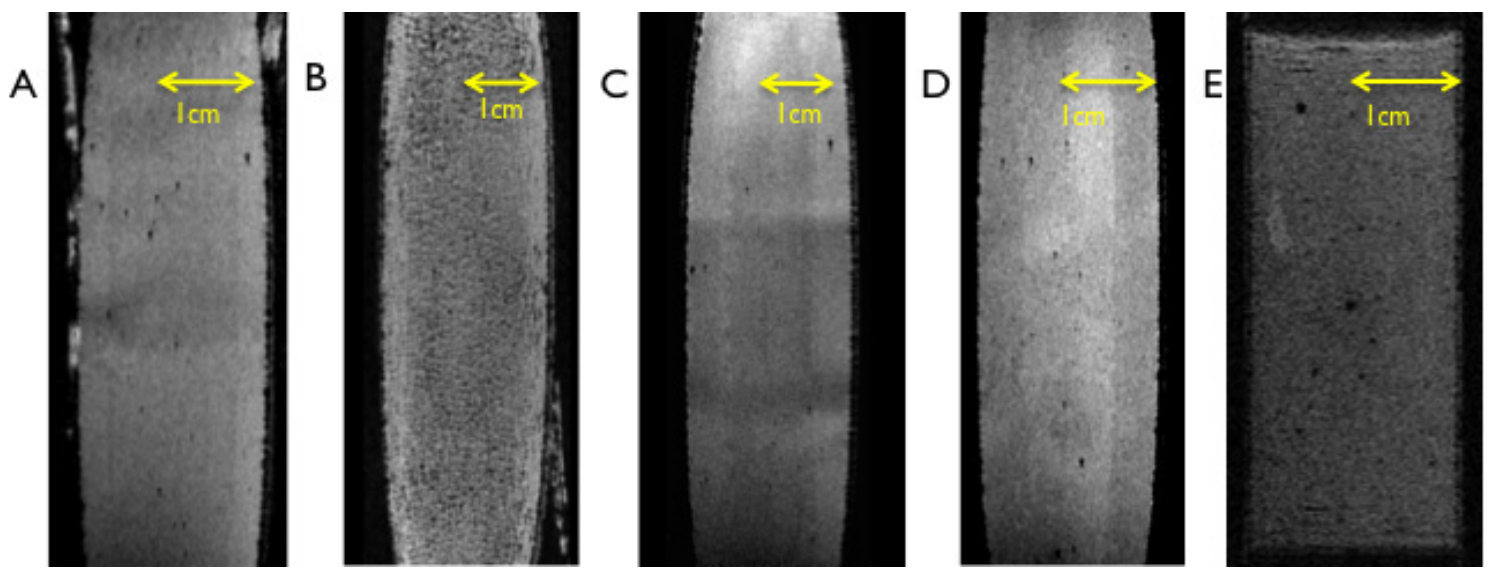

Figure 2: (A-B) A cMR image of the SMCs with a $200 \mu \mathrm{g} / \mathrm{mL}$ concentration of the SPIO particles. (A) Under 24 hours incubation time. (B) Under 48 hours incubation time. (C-D) A cMR image of the ECs under a 24 hours incubation time. (C) With a $100 \mu \mathrm{g} / \mathrm{mL}$ concentration of the SPIO particles. (D) With a $200 \mu \mathrm{g} / \mathrm{mL}$ concentration of the SPIO particles. (E) A cMR image of the PDLSCs with a $200 \mu \mathrm{g} / \mathrm{mL}$ concentration of the SPIO particles under 24 hours incubation time.

Proliferation and Viability: Figure 3 and Figure 4 below show the proliferation and viability for the vascular cells (SMCs and ECs) unlabeled, and labeled for the three SPIO concentrations previously described after a 48 hour incubation time. Figure 5 and Figure 6 show the proliferation and viability for the PDLSC unlabeled and labeled at $200 \mathrm{ug} / \mathrm{mL}$. No significant (N.S, $\mathrm{p}>0.05$ ) values 
were found between proliferation and viability between labeled and unlabeled cells (SMCs, ECs, and PDLSCs). Viability for SMCs unlabeled cells (UC) was $89 \pm 3.5 \%$, while for labeled cells (LC) it was $75 \pm 3 \%$. ECs, viability of UC was $89.8 \pm 2.7 \%$, and LC was $87 \pm 2 \%$. As for PDLSC (UC) was $96 \pm 1.3 \%$, while for labeled cells (LC) it was $94 \pm 1 \%$. Proliferation of all cell types was doubled measured over one week, and values were not significantly different $(p>0.05)$ between LCs and UCs.

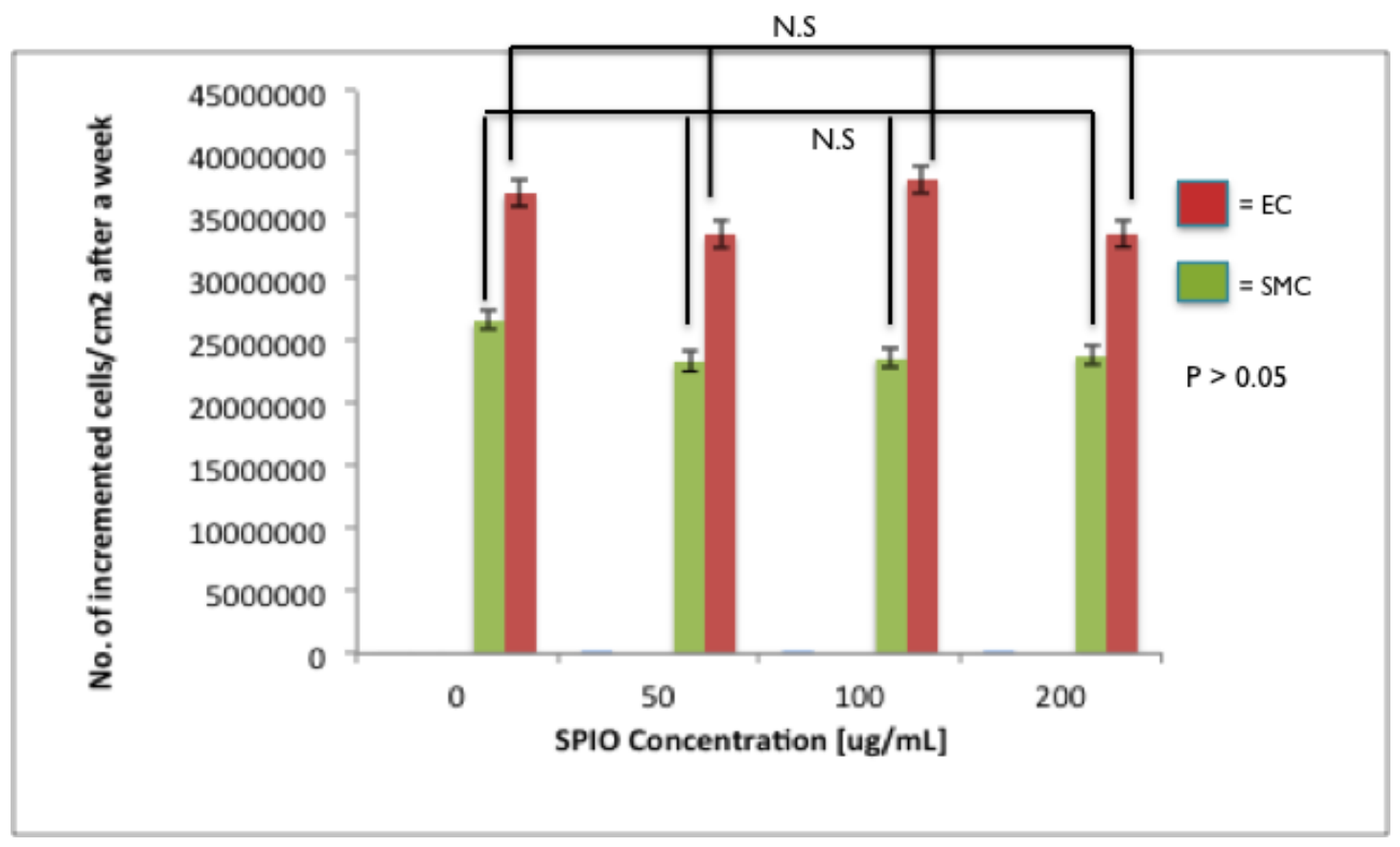

Figure 3: Proliferation of human vascular cells SMC (green) and EC (red) unlabeled, and SPIOlabeled at three different concentrations: 50, 100 and $200 \mathrm{ug} / \mathrm{m}$ in a 48 hour incubation time. The values for both cell types at the different cell concentration did not have any significant differences (N.S) based on the independent t-test $(n=5)$. 


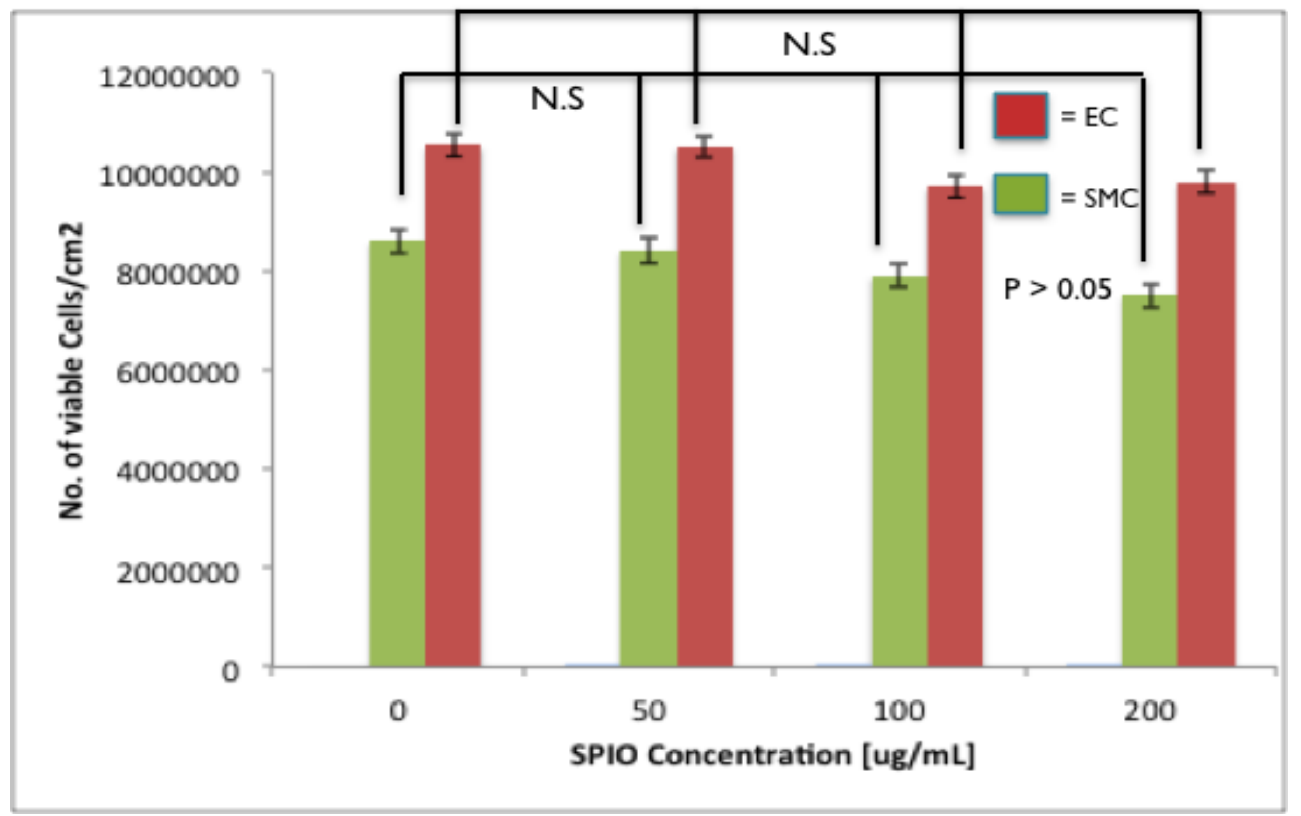

Figure 4: Viability of human vascular cells SMC (green) and EC (red) unlabeled, and SPIO-labeled at three different concentrations: 50,100 and $200 \mathrm{ug} / \mathrm{m}$ in a 48 hour incubation time. The values for both cell types at the different cell concentration did not have any significant differences (N.S) based on the independent $t$-test $(n=5)$.

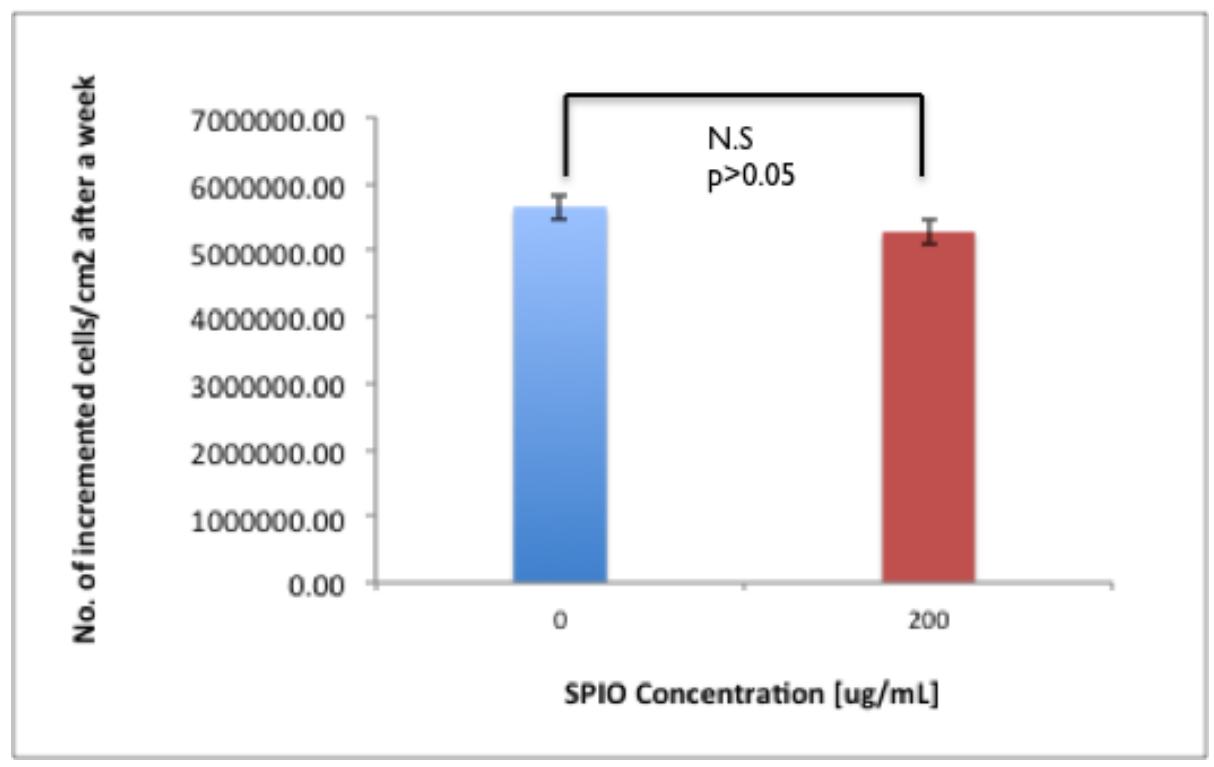

Figure 5: Proliferation for PDLSC's unlabeled and SPIO-labeled at a concentration of $200 \mathrm{ug} / \mathrm{ml}$. There were no statistical differences in the values based on the independent $t$-test $(n=5)$. 


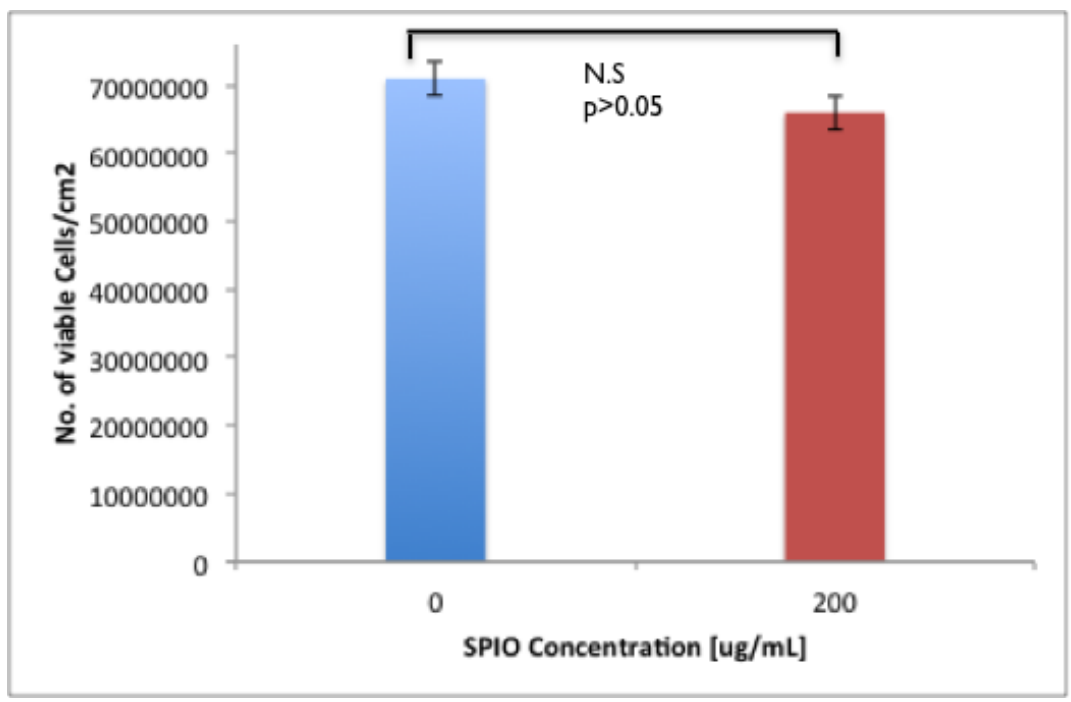

Figure 6: Viability for PDLSCs unlabeled and SPIO-labeled at a concentration of $200 \mathrm{ug} / \mathrm{ml}$. There were no statistical differences in the values based on the independent t-test $(n=5)$.

Iron Oxide Detection: The Prussian blue stain was positive for iron oxide particles inside the cells for the three cell lineages (Figure 7). On the other hand, positive red staining indirectly confirmed intracellular iron oxide uptake as shown in Figure 8 , Figure 9 and Figure 10. 

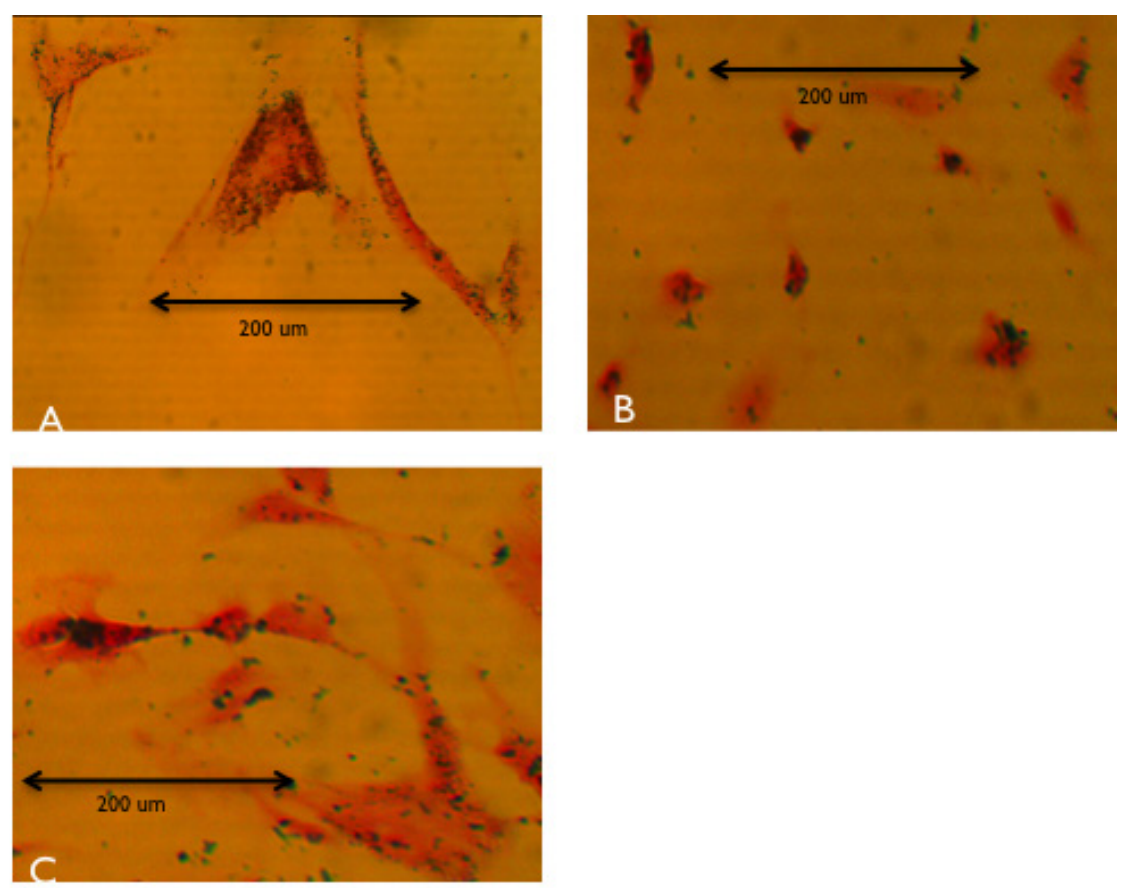

Figure 7: Prussian Blue Stain taken at 100X. Scale bar=200 $\mu \mathrm{m}$. Blue dots represent the iron, while the cytoplasm is shown in a light pink color. (A) SMCs, (B) ECs and (C) PDLSCs cell populations.
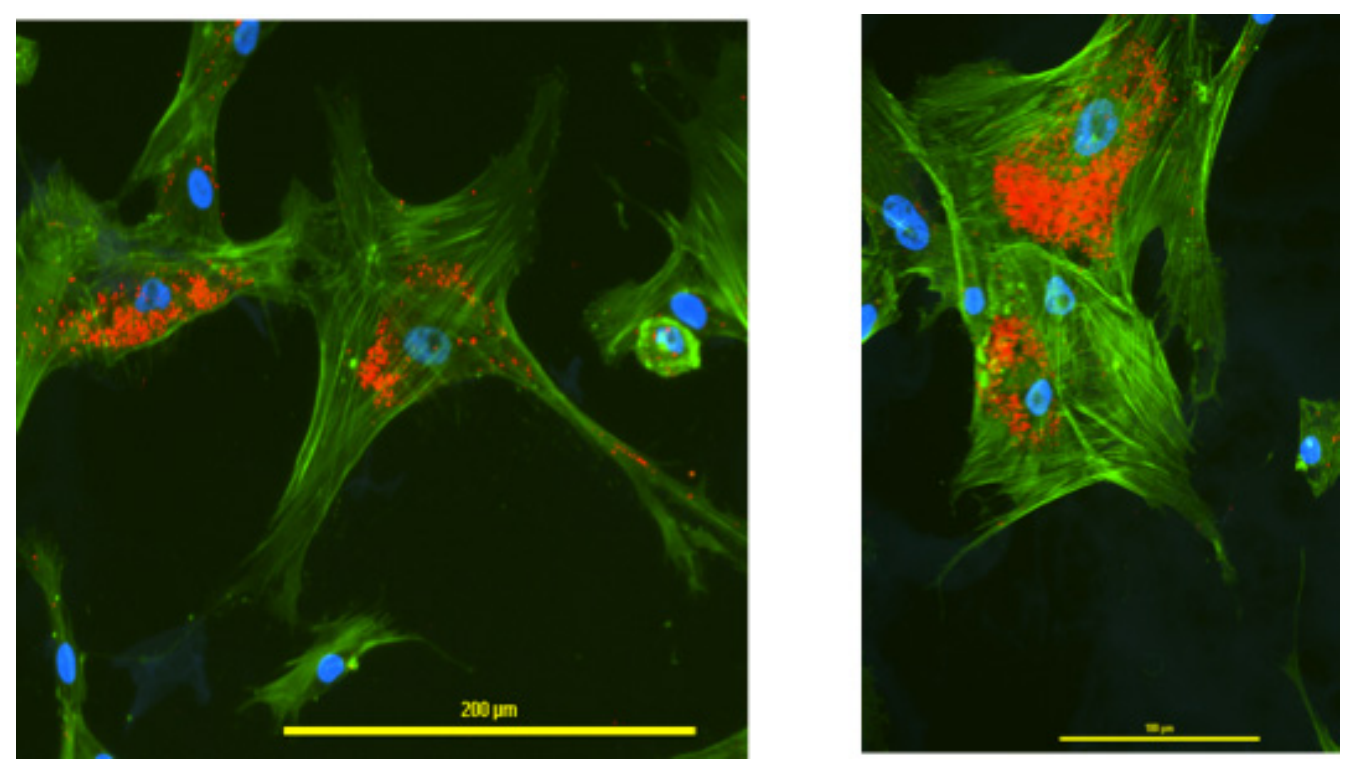

Figure 8: Immunofluorescence of SMCs taken at 100X, Scale bar=200 $\mu \mathrm{m}$ (Left) and 200X, Scale bar $=100 \mu \mathrm{m}$ (Right). Both images were stained for F-actin (green), DAPI (blue) and the fluorescence from the Bangs particles (red). 

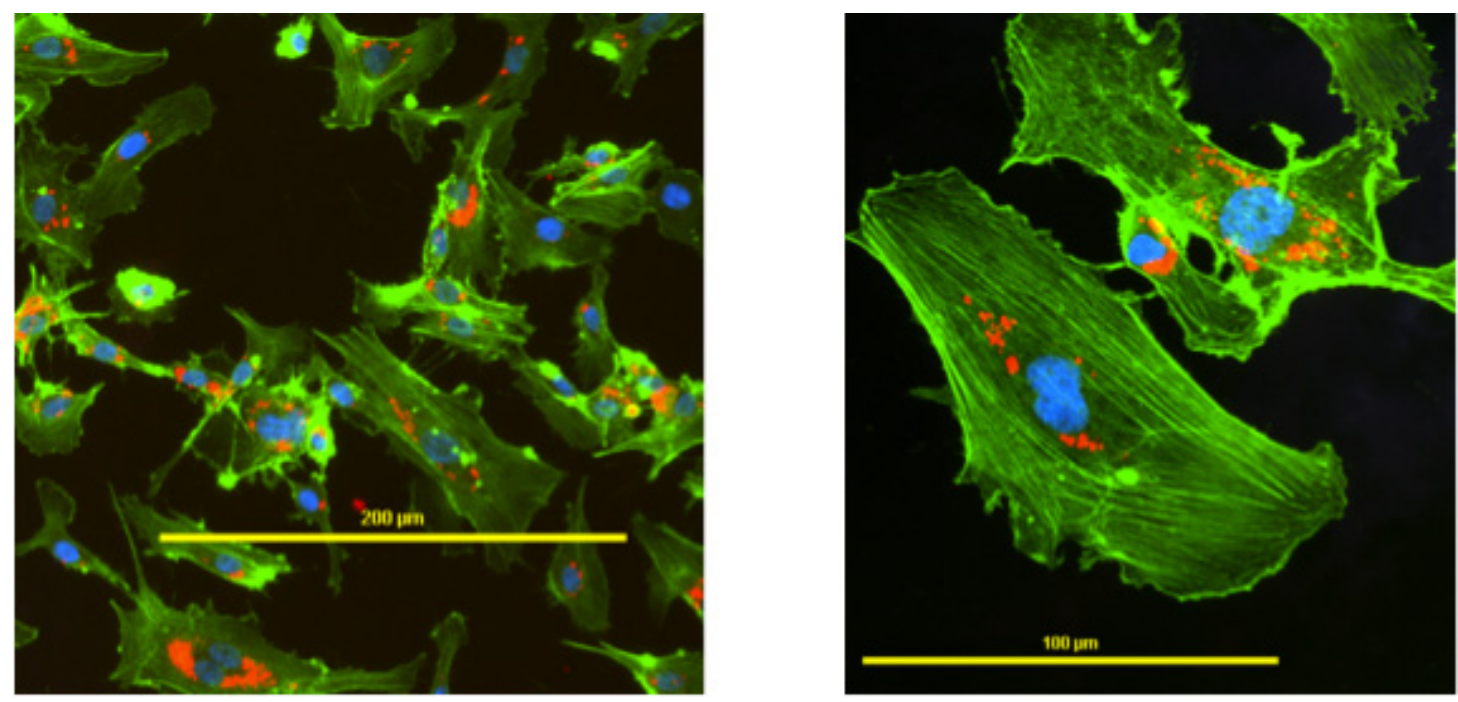

Figure 9: Immunofluorescence of ECs taken at 100X, Scale bar=200 $\mu \mathrm{m}$ (Left) and 400X, Scale bar $=100 \mu \mathrm{m}$ (Right). Both images were stained for F-actin (green), DAPI (blue) and the fluorescence from the Bangs particles (red).
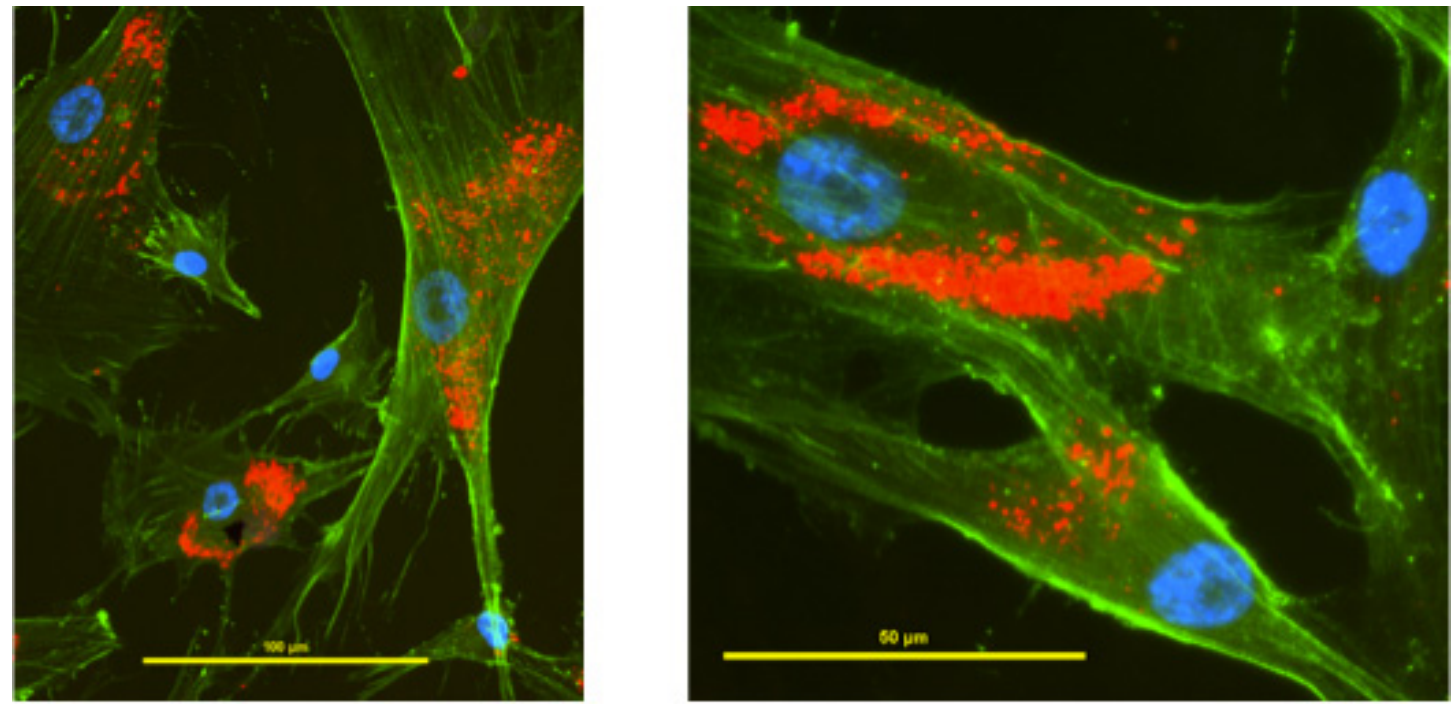

Figure 10: Immunofluorescence of PDLSCs taken at 100X, Scale bar $=200 \mu \mathrm{m}$ (Left) and 200X, Scale bar $=50 \mu \mathrm{m}$ (Right). Both images were stained for F-actin (green), DAPI (blue) and the fluorescence from the Bangs particles (red).

qRT-PCR for SMC, EC and PDLSC Marker Genes: The change in cycle threshold $(\Delta \mathrm{Ct})$ values were averaged and normalized with GAPDH using the $\Delta \Delta \mathrm{Ct}$ method (38). Fold changes were calculated as $2^{-\Delta \mathrm{Ct}}$ and the gene 
expression ratio of each of the three types of cells (SMCs, ECs and PDLSCs) unlabeled relative to labeled indicated as shown on Figure 11, Figure 12 and Figure 13. Specifically, for SMCs GAPDH, B-1 integrin and Thy-1 were both expressed with no significant differences in UC and LC. For ECs, GAPDH, Flk-1, and VE-Cadherin were all expressed with no significant differences; while PECAM-1 was greatly expressed in LC compared to UC, and Tie-1 was expressed greatly in UC compared to LC. Lastly, for PDLSCs, GAPDH, Klf4, and Nestin were all expressed with no significant differences in both UC and LC. Also, Slug was expressed greatly in UC compared to LC.

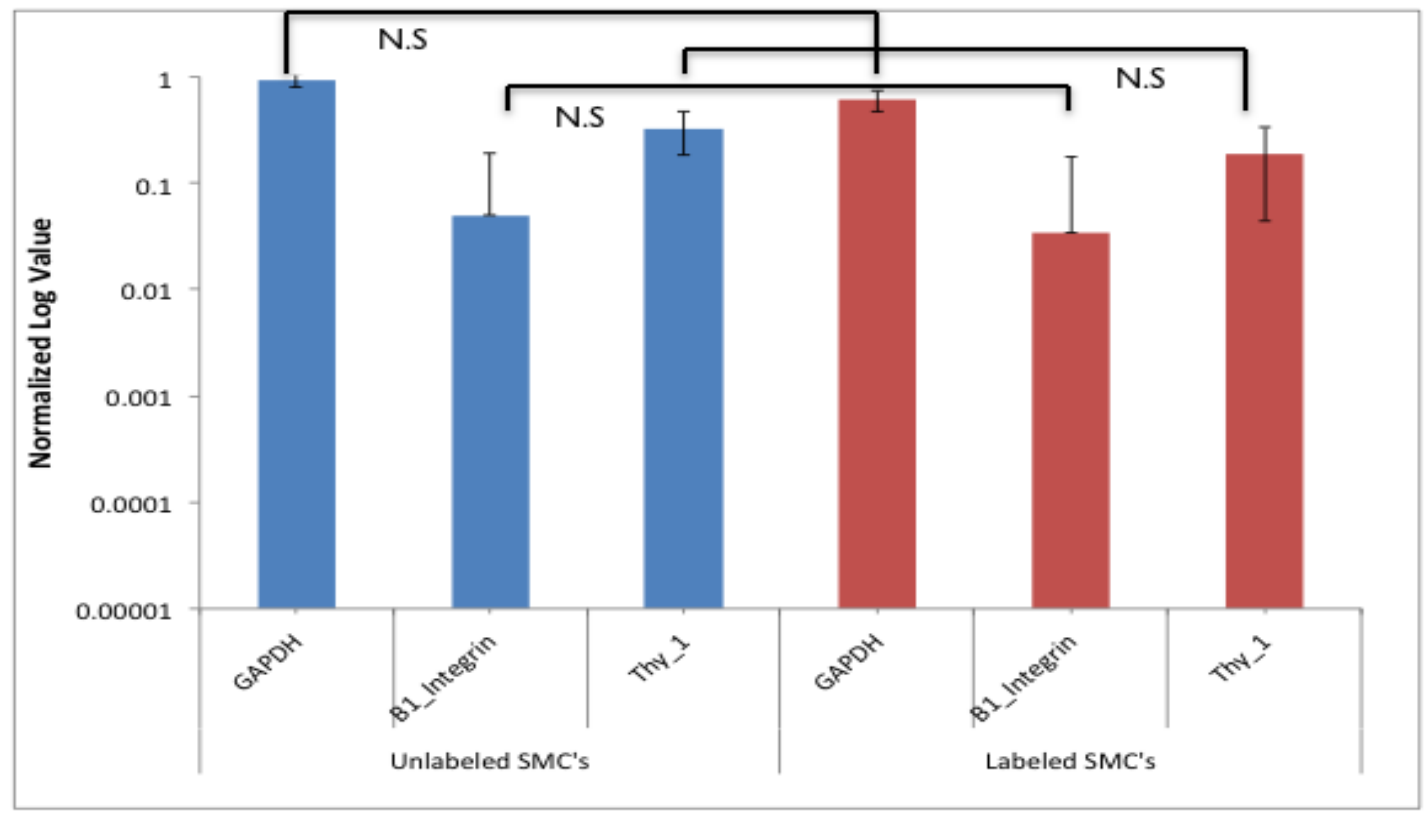

Figure 11: Quantitative RT-PCR of SMC unlabeled (2) and labeled with SPIO microparticles (2). Each column is normalized by GAPDH (endogenous gene). Values for all genes were not statistically different $(n=3)$. 


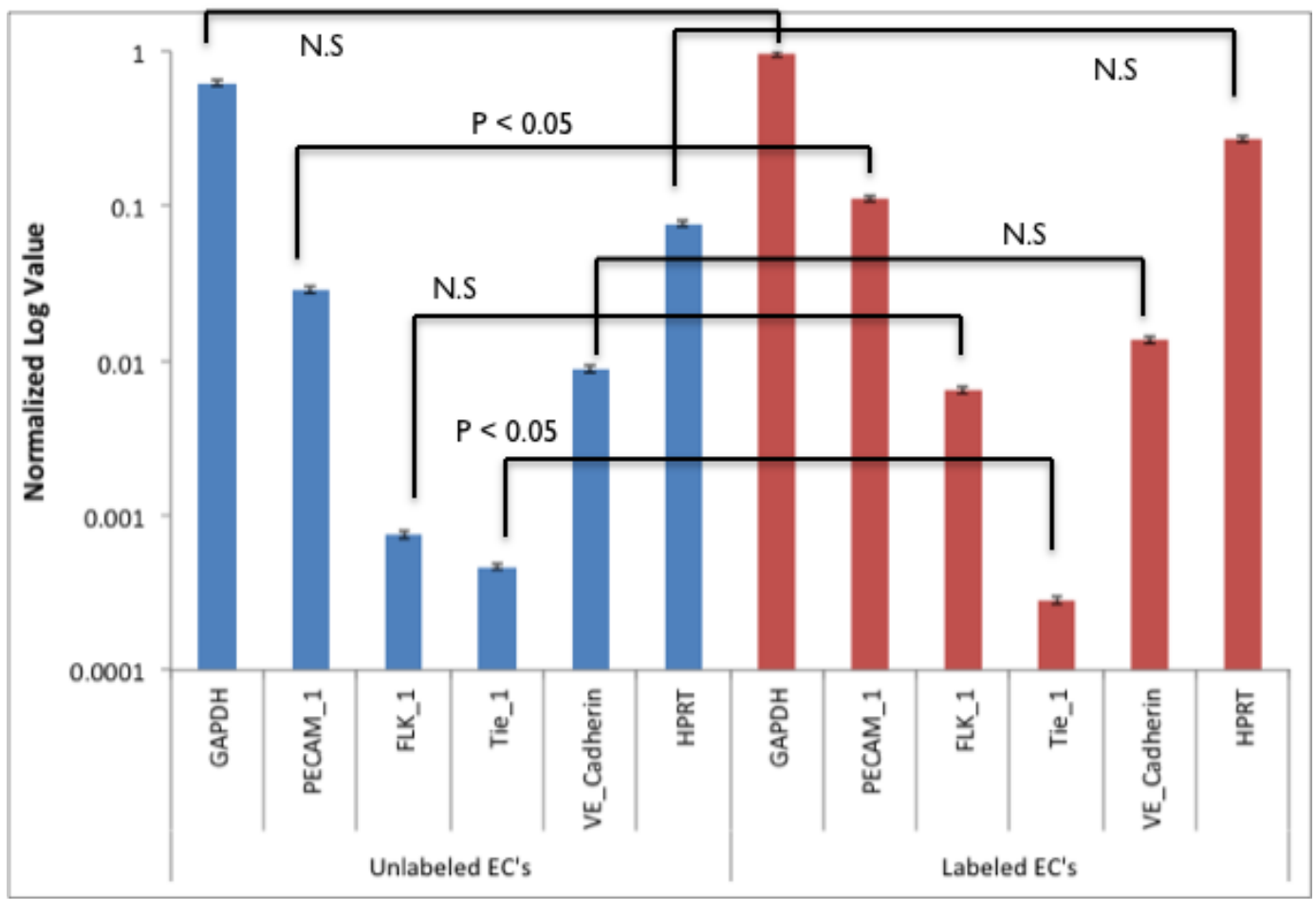

Figure 12: Quantitative RT-PCR of EC unlabeled (5) and labeled with SPIO microparticles (5). Each column is normalized by GAPDH. Values for all genes were not statistically different with exception of PECAM 1 and Tie $1(P<0.05)(n=3)$. 


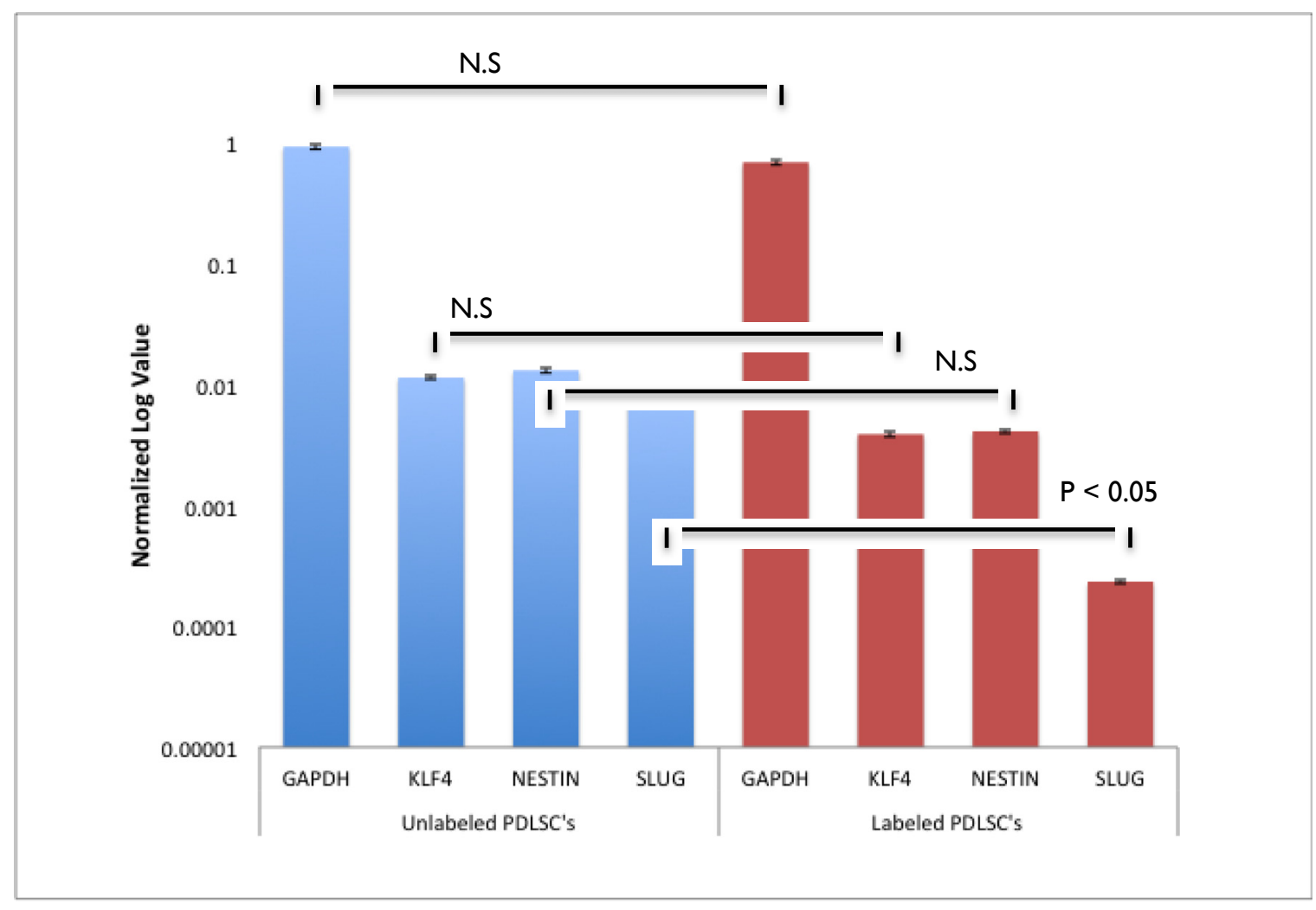

Figure 13: Quantitative RT-PCR of PDLSC unlabeled (5) and labeled with SPIO microparticles (5). Each column is normalized by GAPDH. Values for all genes were not statistically different with exception of Sox 2 and Slug $(P<0.05)(n=3)$.

Treatments for congenital heart valve disease clearly need advanced procedures for examining the effectiveness of the treatment during in vivo conditions. MRI can be utilized in cellular processes to longitudinally track the fate of cells seeded on a specific scaffold. Noninvasive longitudinal monitoring by means of MRI is increasingly being utilized on processes related to cell and tissue engineering. These developments can drastically aid in the evaluation of tissue-engineered constructs $(39,40)$. SPIO nanoparticles have been demonstrated to work in MRI investigations without harming the cell in any way (24-28). Terrovitis et al. showed that labeling BMSC's with ferumoxides was not toxic to the cells, and they could even be further visualized in collagen gels/scaffolds (26). In another study performed by Ko et al (29) cellular MRI 
methodologies were demonstrated to allow for visualization of an implanted scaffold as well as the cellular behavior around the scaffold in a mouse model. He utilized SPIO-labeled-hMSCs, which were then cultured in a scaffold: gelatin sponge to support cell growth and proliferation (29). In a similar manner, MRI has been reported to be useful in monitoring tissue engineering heart valve (TEPV) growth and function in-vivo by Hill et al (22). As mentioned earlier, MRI allows cell detection by accelerated $\mathrm{T}^{*}$ decay, which are represented as hypointense regions caused by the intracellular iron oxide particles (41). This visualization is necessary from the beginning of the in-vitro culturing period of the engineered construct and could in theory be progressively tracked, even after implantation (41). Harrington et al (42) utilized cellular MRI to track the fate of SPIO labeled macrophages seeded onto functional tissue engineered vascular grafts (TEVGs) through serial imaging. In their study, seeded cells were rapidly lost from implanted scaffolds instead of progressing into cells in the neovessel as hypothesized by their group. However, their findings were a successful application of noninvasive MRI for a serial study of cellular level processes in tissue engineering (42).

In this study, the three cell lineages (SMCs, ECs and PDLSCs) proliferate and were viable after being labeled with SPIO microparticles at $200 \mu \mathrm{g} / \mathrm{mL}$ They were successfully visualized using $\mathrm{T}^{*}$ contrast by MRI 1 week post-labeling. MRI slices were co validated by Prussian blue staining and fluorescence microscopy confirmed the presence of the ferumoxide particles as evidenced by the detection of the co-labeled red tag of the Bang's particles intracellularly. The 
migratory activity of the cells could also be tracked longitudinally during their developmental process, which would permit us to understand their in vivo hemodynamic environment in future work.

\section{RESULTS AND DISCUSSION PART II: PDLSC AS A POTENTIAL}

\section{CELL SOURCE FOR HEART VALVE TISSUE ENGINEERING}

Cell Phenotype: The $\Delta \mathrm{Ct}$ values were averaged and normalized with GAPDH using the $\Delta \Delta \mathrm{Ct}$ method (38). Fold changes were calculated as $2^{-\Delta \mathrm{Ct}}$ and the gene expression ratio of each of the four groups (negative control, differentiating media, BioFlux, and differentiating media + BioFlux) indicated as shown on Figure 14. ANOVA test was performed to compare the four groups pairwise (Table 2 through 7). Table 8 summarizes the gene expression comparison among all groups. Table 9 on the other hand shows the percentage increase of gene expression of all groups compared to group 1. There was an increased percentage of group 4 over groups 2 and 3 in genes Thy-1, Pecam-1 and Flk-1 and Ve-Cadherin.

Based on results from qRT-PCR on Figure 14, P-values from Tables (2 through 7) as well as gene expression comparison (Table 8) and percentage increase comparison (Table 9) it was determined that the highest gene presence for both smooth muscle cells and endothelial cells was produced from RNA extracted from group 4, i.e., PDLSCs exposed to our differentiating media and flow in the BioFlux system $\left(1 \mathrm{dyne} / \mathrm{cm}^{2}\right)$. There was a significant affect $(P<0.05)$ of these two variables for the cells to positively express genes for both smooth muscle (beta-1 integrin and Thy 1) and endothelial (Pecam-1, Flk-1, VE- 
Cadherin) cell phenotypes compared to all other groups. There were also significant differences $(P<0.05)$ in the expression of all genes when comparing them against each other as seen on Tables 2 through 8 . However, these results also showed a considerable effect in the differentiative capacity of PDLSCs based on just flow (group 3) or differentiation medium (group 2) as both of these groups developed gene expression in the qRT-PCR results. The effect of differentiation medium alone on PDLSCs was significant $(P<0.05)$ for $E C$ gene expression over basal medium; however, it was not for SMC gene expression (Tables 2 through 7). Similarly, the effect of flow alone on PDLSCs compared to basal medium without flow was significantly different $(P<0.05)$ for both SMC and EC phenotypes. Therefore flow alone had a higher effect on the differentiative capacity of PDLSCs than the differentiative medium. Our control group (group 1) of cells that were cultured under their regular basal medium did not show significant expression of either SMC or EC phenotypes. 


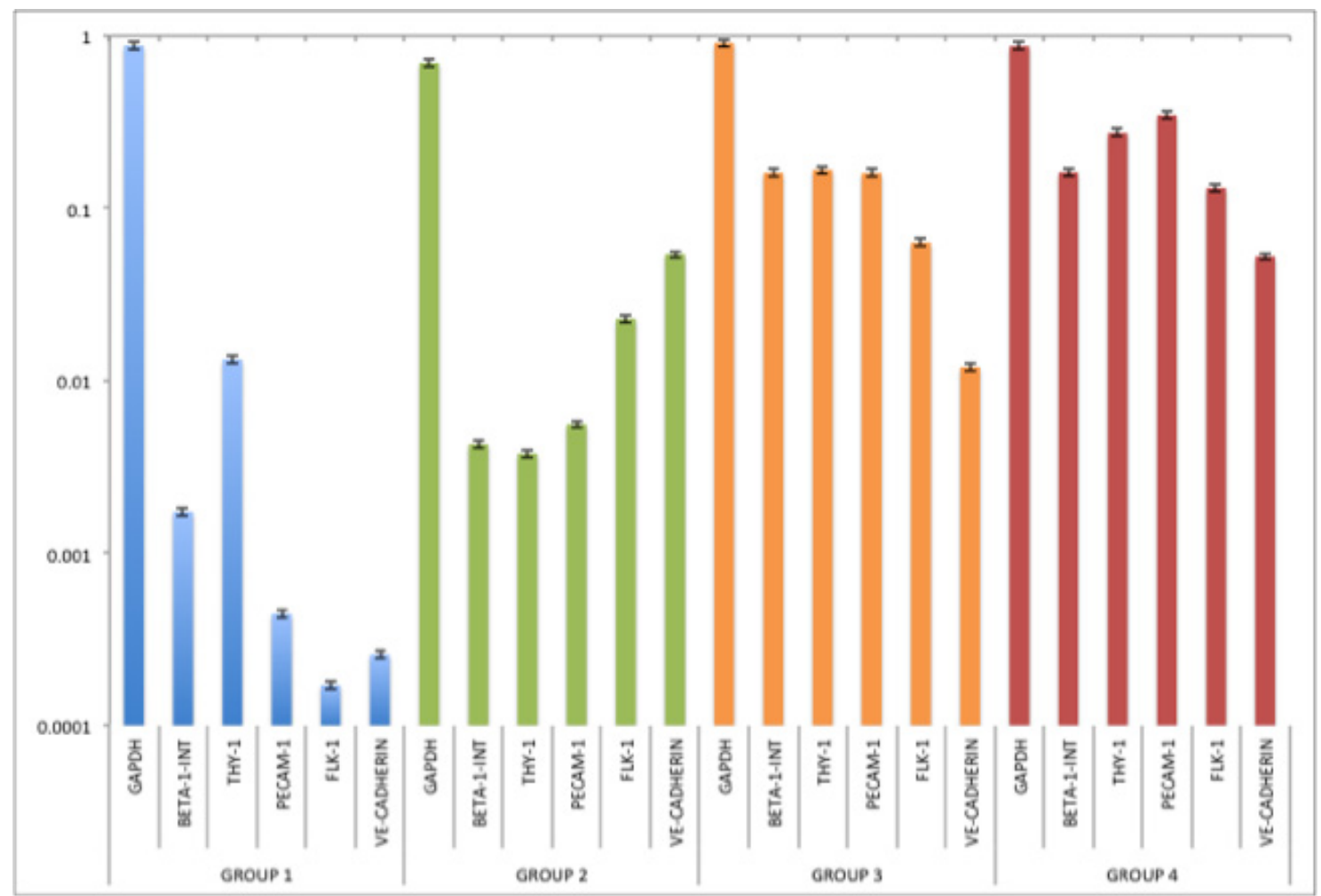

Figure 14: Quantitative RT-PCR of PDLSC $(n=3)$. Group 1: Cells cultured in regular basal medium. Group 2: Cells cultured in differentiating media. Group 3: Cell cultured in basal medium and exposed to $1 \mathrm{dyne} / \mathrm{cm}^{2}$. Group 4: Cells cultured in differentiating media and exposed to $1 \mathrm{dyne} / \mathrm{cm}^{2}$. Each column is normalized by GAPDH.

Table 2: P-value for GAPDH gene expression within the four groups.

\begin{tabular}{|c|c|c|c|c|c|}
\hline GAPDH & $\begin{array}{l}\text { Sum of } \\
\text { Squares } \\
\text { (SS) }\end{array}$ & $\begin{array}{l}\text { Degrees of } \\
\text { Freedom } \\
\text { (df) }\end{array}$ & $\begin{array}{l}\text { Mean of } \\
\text { Squares } \\
\text { (MS) }\end{array}$ & F-Test & P-Value \\
\hline Groups & 0.78 & 3 & 0.26 & \multirow[t]{3}{*}{6.97} & \multirow[t]{3}{*}{0.0127} \\
\hline Error & 0.30 & 8 & 0.04 & & \\
\hline Total & 1.08 & 11 & & & \\
\hline
\end{tabular}

Table 3: P-value for Beta-1-Integrin gene expression within the four groups.

\begin{tabular}{|c|c|c|c|c|c|}
\hline $\begin{array}{l}\text { Beta-1- } \\
\text { Integrin }\end{array}$ & SS & df & MS & F-Test & P-Value \\
\hline Groups & 79.35 & 3 & 26.45 & 47.2 & $1.97 \times 10^{\wedge} 5$ \\
\hline Error & 4.48 & 8 & 0.56 & & \\
\hline Total & 83.83 & 11 & & & \\
\hline
\end{tabular}


Table 4: P-value for THY-1 gene expression within the four groups.

\begin{tabular}{|c|c|c|c|c|c|}
\hline THY-1 & ss & df & MS & F-Test & P-Value \\
\hline Groups & 45.84 & 3 & 15.28 & 17.99 & 0.0006 \\
\hline Error & 6.79 & 8 & 0.85 & & \\
\hline Total & 52.63 & 11 & & & \\
\hline
\end{tabular}

Table 5: P-value for PECAM-1 gene expression within the four groups.

\begin{tabular}{|c|c|c|c|c|c|}
\hline PECAM-1 & ss & df & MS & F-Test & P-Value \\
\hline Groups & 162.39 & 3 & 54.13 & 277.59 & $2.01 \times 10^{\wedge} 8$ \\
\hline Error & 1.56 & 8 & 0.20 & & \\
\hline Total & 163.95 & 11 & & & \\
\hline
\end{tabular}

Table 6: P-value for FLK-1 gene expression within the four groups.

\begin{tabular}{|c|c|c|c|c|c|}
\hline FLK-1 & ss & df & MS & F-Test & P-Value \\
\hline Groups & 156.67 & 3 & 52.22 & 124.58 & $4.71 \times 10^{\wedge} 7$ \\
\hline Error & 3.35 & 8 & 0.42 & & \\
\hline Total & 160.02 & 11 & & & \\
\hline
\end{tabular}

Table 7: P-value for VE-CADHERIN gene expression within the four groups.

\begin{tabular}{|c|c|c|c|c|c|}
\hline $\begin{array}{l}\text { VE- } \\
\text { CADHERIN }\end{array}$ & SS & df & MS & F-Test & P-Value \\
\hline Groups & 119.20 & 3 & 39.73 & 26.8 & 0.0002 \\
\hline Error & 11.86 & 8 & 1.48 & & \\
\hline Total & 131.06 & 11 & & & \\
\hline
\end{tabular}

Table 8: Gene expression comparison among all groups

\begin{tabular}{|l|l|}
\hline Groups being compared & Genes significantly different from Group $4 \mathbf{( p < 0 . 0 5 )}$ \\
\hline Group 1 vs. Group 4 & B-1-integrin, Thy 1, Pecam-1, Flk-1, Ve-cadherin \\
\hline Group 2 vs. Group 4 & B-1-integrin, Thy 1, Pecam-1, Flk-1 \\
\hline Group 3 vs. Group 4 & Ve-Cadherin \\
\hline
\end{tabular}


Table 9: Percentage Increase of Gene Expression per Group Compared to Group 1

\begin{tabular}{|l|c|c|c|}
\hline & GROUP 2 VS. GROUP 1 & GROUP 3 VS. GROUP 1 & GROUP 4 VS. GROUP 1 \\
\hline $\begin{array}{l}\text { BETA-I- } \\
\text { INTEGRIN }\end{array}$ & $59.43 \%$ & $98.92 \%$ & $98.93 \%$ \\
\hline THY-1 & & & $95.15 \%$ \\
\hline PECAM-1 & $-251.80 \%$ & $92.06 \%$ & $99.87 \%$ \\
\hline FLK-1 & $92.07 \%$ & $99.72 \%$ & $99.887 \%$ \\
\hline VE-CADHERIN & $99.25 \%$ & $97.86 \%$ & $99.51 \%$ \\
\hline
\end{tabular}

Immunohistochemistry: PDLSCs from group 1 (negative control) did not stain positive for either alpha-sma or VWF (Figure 15 (A and B)). While PDLSCs from group 2 showed positive staining for both gene markers (Figure 15C, 15D). In a similar manner, PDLSCs from groups 3 and 4 stained positively for both smooth muscle (alpha-sma) and endothelial cell markers (VWF) (Figure 16 (A and B); and Figure (16 and D)). Positive staining was confirmed with positive controls, i.e. smooth muscle cells and endothelial cells (Figure 17 (A and B)). 

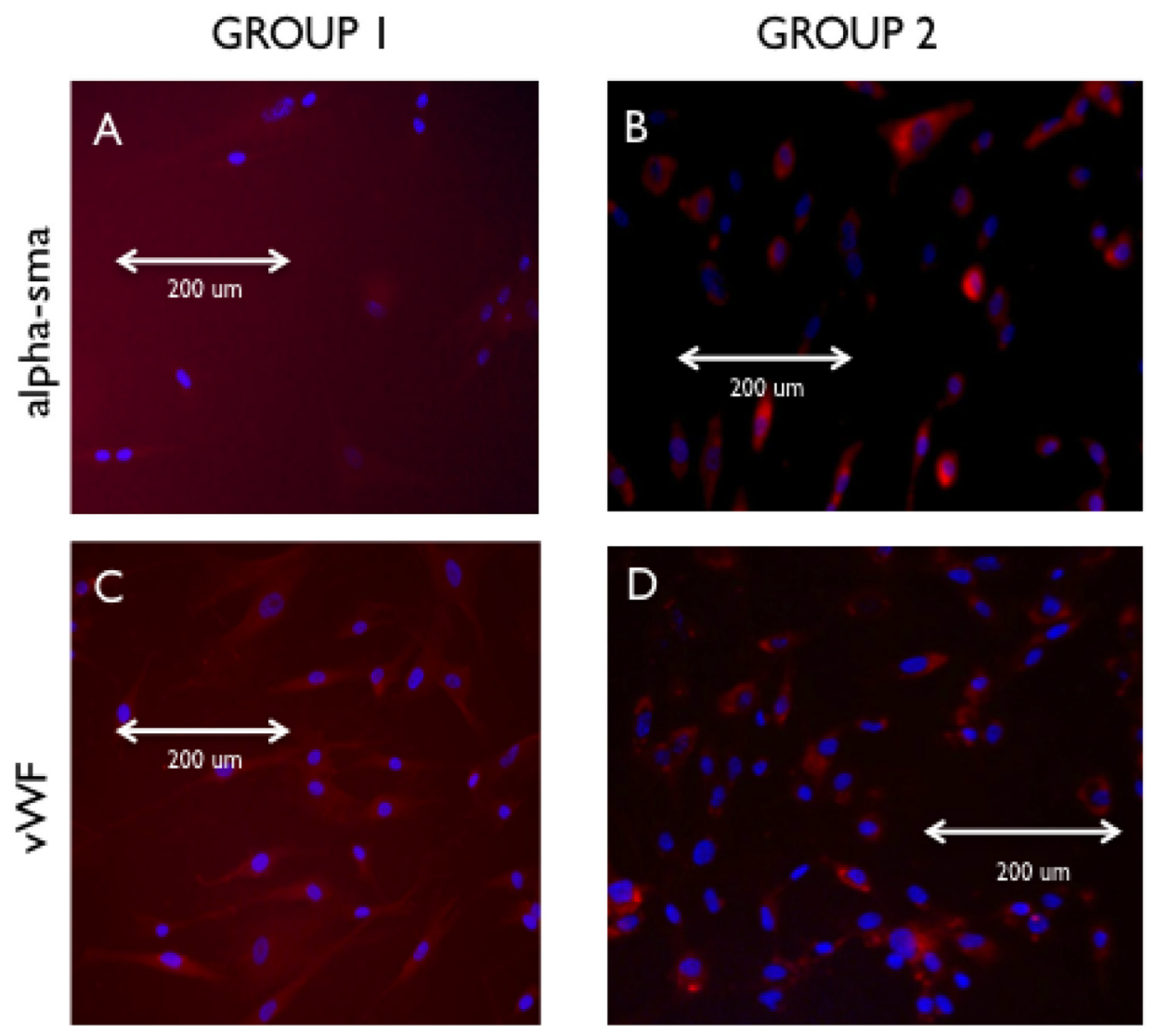

Figure 15: (A and $B$ ) represents staining for alpha-sma for cells from group 1: negative staining (A) and group 2: positive staining (B), while Figure 9(C and D) represents staining for vWF for cells from group 1: negative staining (A) and group 2: positive staining (B). DAPI (Blue) marks the nucleus of the cells, while Texas Red (Red) marks either alpha-sma ( $A$ and $C$ ) or vWF (B and D). The images were taken at $20 \mathrm{X}$, on an upright fluorescent microscope. 


\section{GROUP 3}
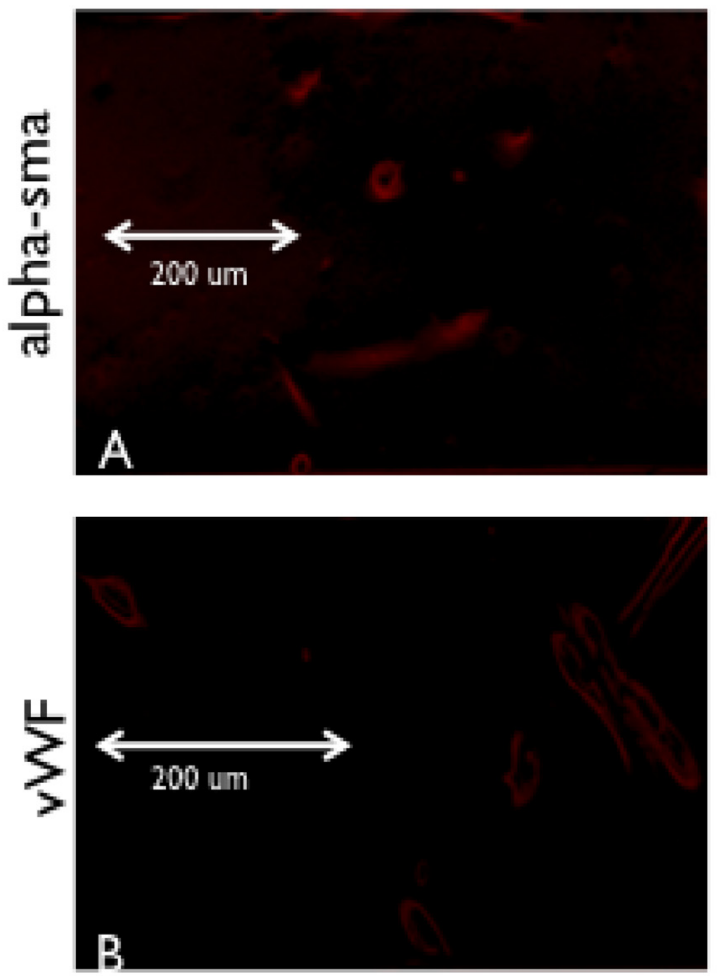

GROUP 4
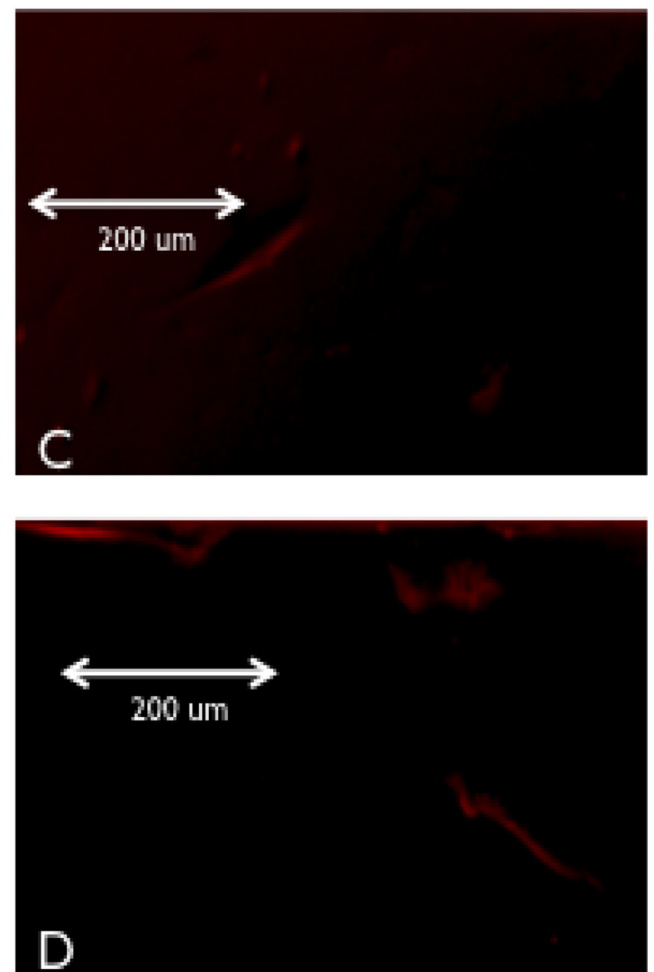

Figure 16: (A and $C$ ) represents positive staining for alpha-sma for cells from group $3(A)$ and group 4 (B), while Figure 10(B and $D$ ) represents positive staining for vWF for cells from group $3(A)$ and group 4 (B). Texas Red (Red) marks either alpha-sma (A and C) or vWF (B and D). The images were taken at 20X, on an inverted fluorescent microscope.

\section{alpha-sma}

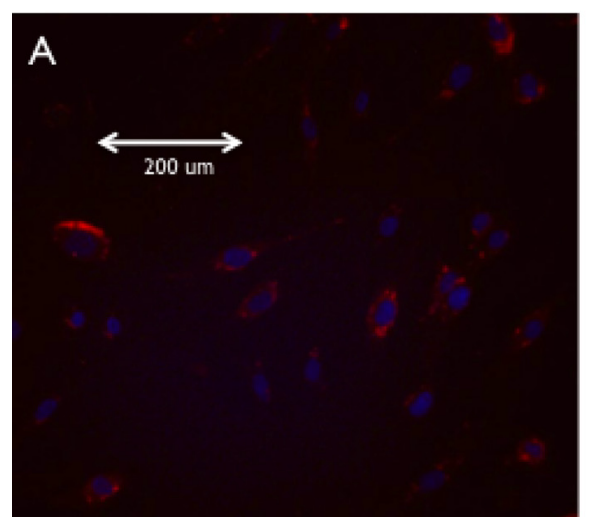

VWF

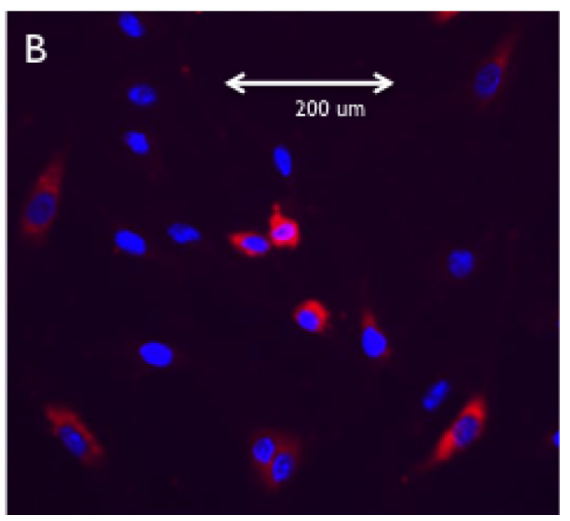

Figure 17: (A) represents positive staining to alpha-sma for mooth muscle cells, while (B) represents positive staining for vWF for endothelial cells. DAPI (Blue) marks the nucleus of the cells, while Texas Red (Red) marks either alpha-sma (A ) or vWF (B). The images were taken at 20X, on an upright fluorescent microscope. 
Over the past decade, the potential of BMSCs to provide regenerative treatment strategies in cardiac disease have been investigated (1,5-9). Researchers have found that MSCs differentiate in vitro into cardiomyocytes and smooth muscle cells, however, there has not yet been clear evidence of MSCs differentiation to endothelial lineages under solely biomechanical environments $(8,43,44)$. Embryonic stem cells (ESCs), on the other hand have been shown to have a high potency to develop cardiac phenotypes including both SMCs and ECs $(13,14)$. In our study we utilized PDLSCs because subpopulations of this cell lineage have shown to express ESCs markers (Oct4, Sox2, Nanog, and Klf4), therefore exhibiting a higher differential potential than MSCs (12). Owing to their more primitive state, PDLSCs offer the possibility to differentiate into neurogenic (ectoderm), as well cardiomyogenic, osteogenic and chondrogenic (mesoderm) cell lineages suggesting extensive pluripotency capacities. To date, the only pluripotent stem cells with capacity to differentiate into the three germal layers (ectoderm, mesoderm and endoderm) are ESCs, however, based on recent findings by Huang et al (12) PDLSCs may provide similar pluripotency and perhaps the only cell type that can be derived from adults. In addition, PDLSCs can easily be culture expanded and are potentially more immune-tolerant compared to BMSCs, and therefore could be used in an allogenic manner. These properties make PDLSCs an especially attractive cell source for cardiovascular tissue engineering therapeutics for use in applications such as severe congenital heart valve disease and anomalies. 
After examining phenotypic changes in the PDLSCs from all four groups using immunohistochemistry and RT-PCR we found out that there is a significant effect of culturing the cells with our differentiating cocktail media containing and dynamic conditioning by means of flow $\left(1 \mathrm{dyne} / \mathrm{cm}^{2}\right)$. Also, the use of only cocktail media, or shear stress $\left(1 \mathrm{dyne} / \mathrm{cm}^{2}\right)$ also has an effect in valve like expression. However, flow has a much more dominant effect in comparison to biochemical stimulants in differentiating PDLSCs into valve phenotypes.

\section{RESULTS AND DISCUSSION PART III: VASCULAR CELL MIGRATORY ACTIVITY UNDER DYNAMIC STATES COMPARED TO STATIC CONTROLS BY SPIO-LABELED CELLS}

To observe cell behavior in a scaffold environment under static and steady flow states, we scaled up our studies to 3-D culture, with a focus on cell detection, visualization and distribution using the PDLSCs.

MR Imaging: SPIO-labeled PDLSCs seeded in the PGA/PLLA scaffold under rotisserie culture for 1 week and subsequently housed in our u-shaped bioreactor were successfully labeled under a concentration of $200 \mu \mathrm{g} / \mathrm{ml}$ (Figure 18). The MRI scan parameters for the resulting $T 2^{*}$-weighted images that were acquired were with $60 \mathrm{~mm}$ resolution and $11.2 \mathrm{~ms}$ TE and $100 \mathrm{~ms}$ TR. 


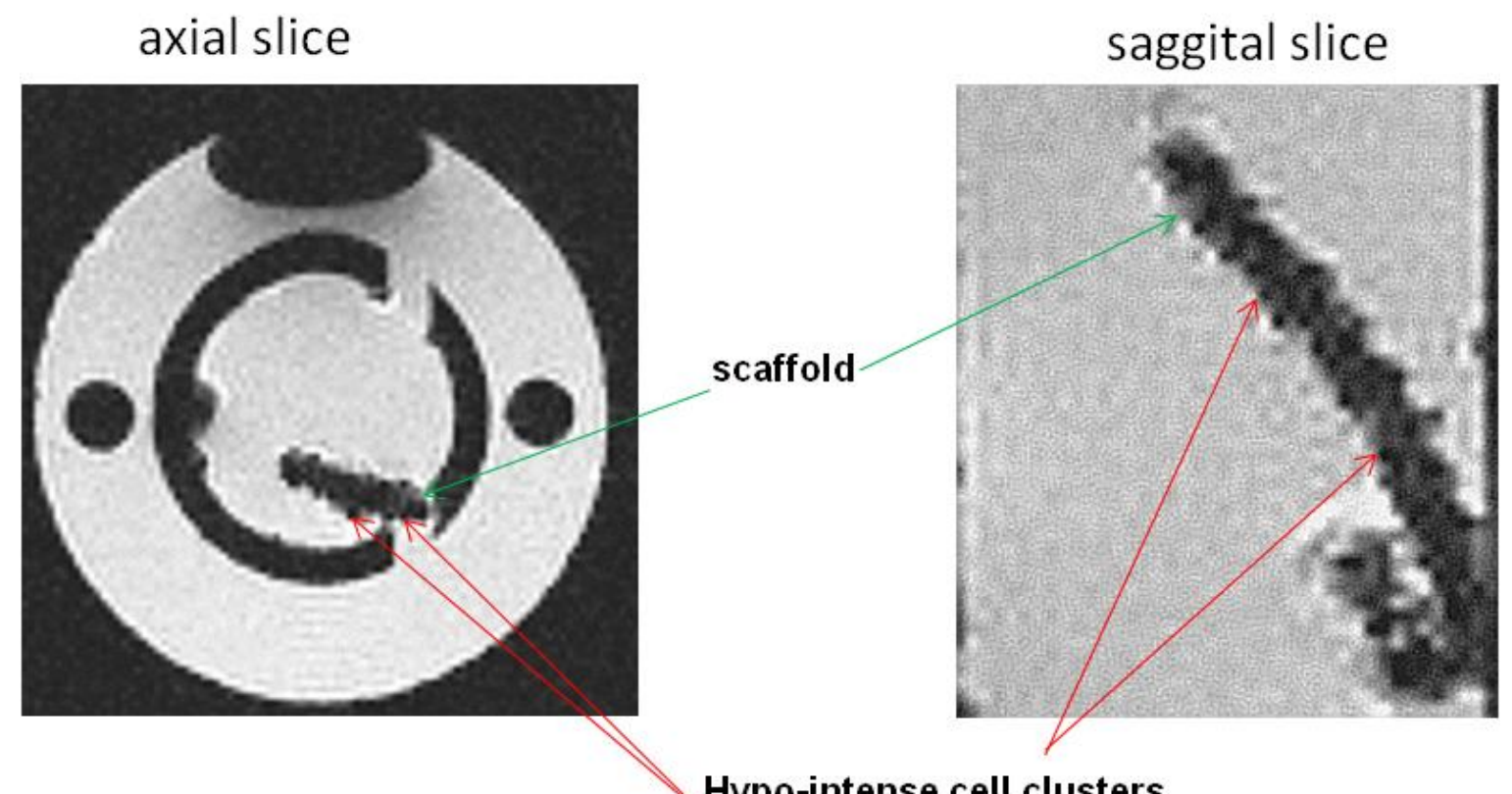

Hypo-intense cell clusters

Figure 18: MRI of PDLSC-seeded scaffolds in situ within the U-shaped bioreactor. The figure shows axial and sagittal slices from T2*-weighted images. Dark spots within the scaffold region are cells, which are hypointense due signal attenuation caused by the intracellular SPIO micro-particles.

Histology: We report representative histology for the PDLSCs, which were fixed and embedded with paraffin at different time points, cut in a microtome at $10 \mu \mathrm{m}$ in the axial direction, and stained for hematoxilyn and eosin (H\&E) for general morphology (Figure 19). More cells were observed when cultured under flow conditions; meaning flow allows more cells to remain viable. Also, changes in morphology under flow states suggest induced differentiation. 

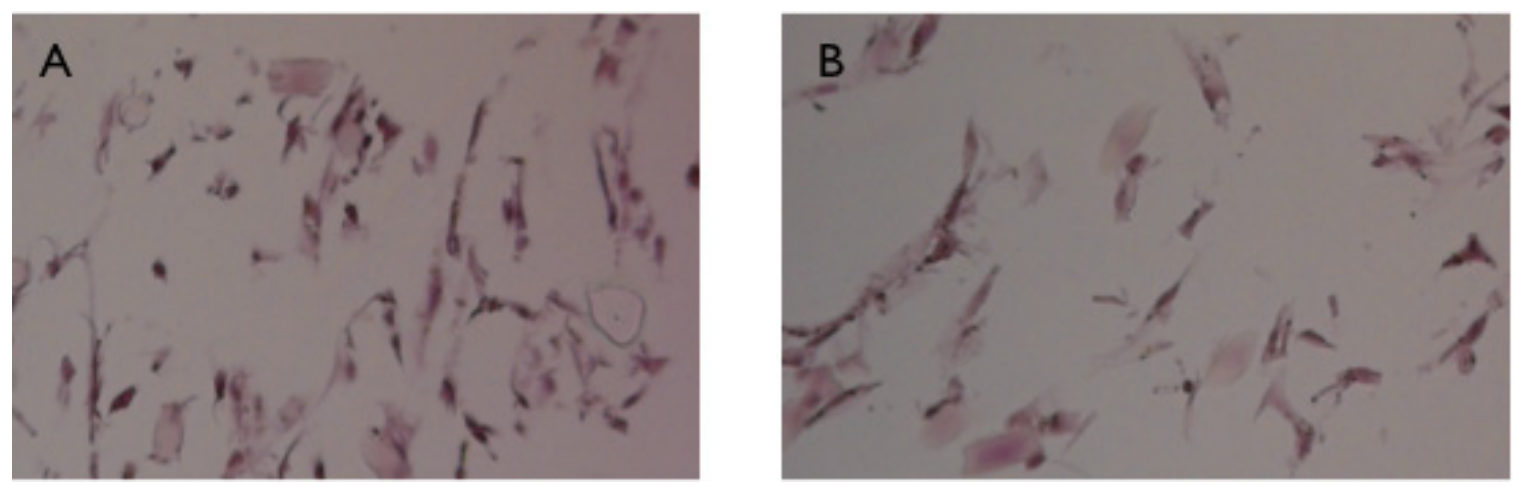

Figure 19: H\&E staining for general tissue assessment and organization of PDLSCs 2 weeks of culturing (A): Cultured under flow conditions. (B): Cultured under static conditions. Magnification is 20x.

Fluorescent Validation for PDLSC seeded scaffold: Sections were also mounted and stained for DAPI with Vectashield Mounting Media (Invitrogen, Carlsbad, CA)) and examined under an inverted fluorescent microscope to further validate the MR image for presence of the red tag contained in the Bangs particles for further validation of the iron oxide presence inside the cells (Figure 20). 

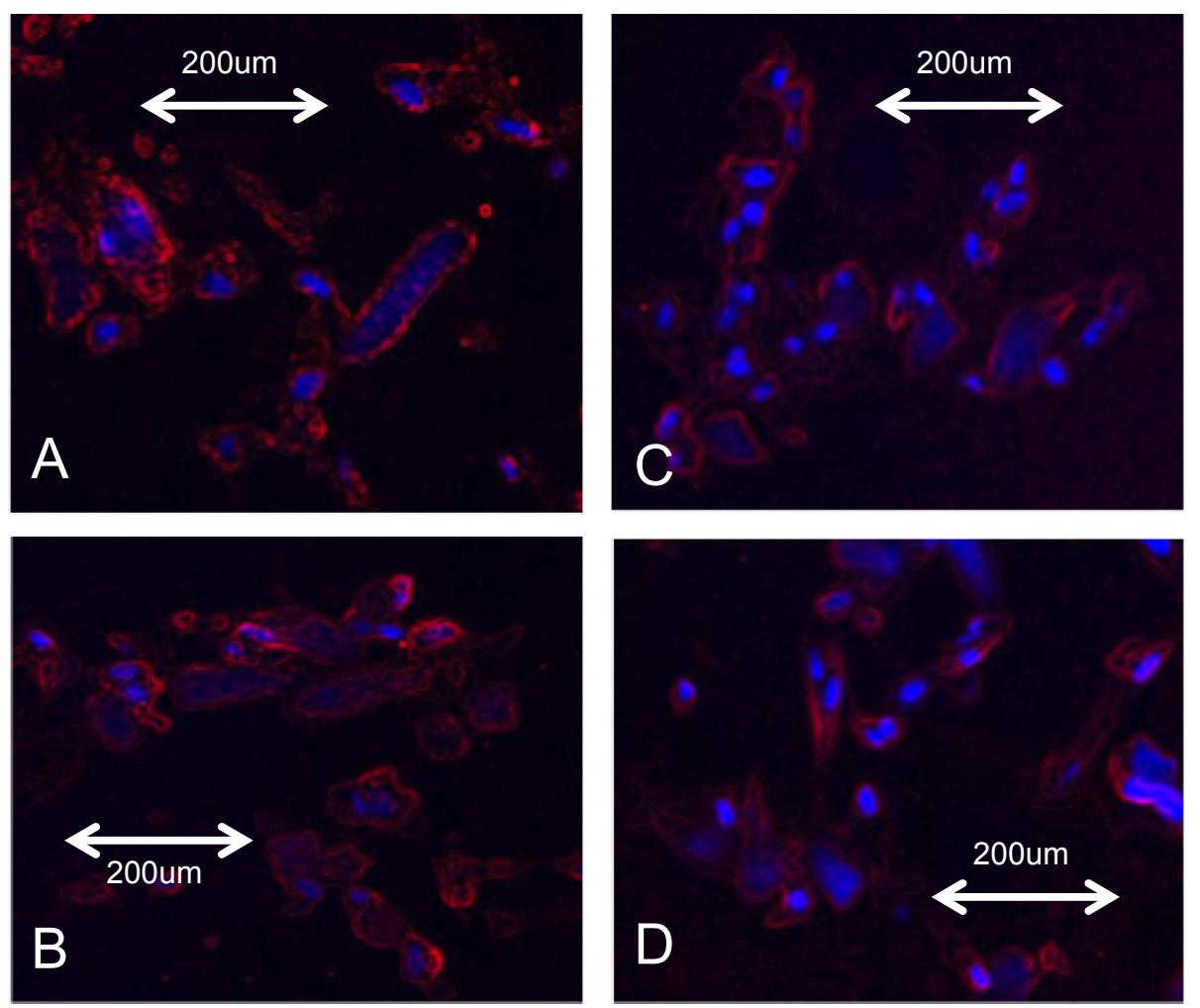

Figure 20: Immunofluorescence of PDLSC seeded scaffold (A-B) Cultured under static conditions (C-D) Cultured under flow conditions. Magnification is 20x. DAPI (nucleus), and Red (Bangs Particles).

DNA Quantification for SMC-EC-seeded Scaffolds: Based on our seeding density of $2 \times 10^{6}$ cells/scaffold, and results from Engelmayr et al (1) suggesting a seeding efficiency of $90 \%$ when utilizing PGA/PLLA as the scaffolding material we assumed that an average of 180,000 cells/scaffold were retained. Assuming a DNA content of $7.6 \mathrm{pg} / \mathrm{cell}$ (45), there was an initial DNA content of $13.68 \mathrm{ug} / \mathrm{scaffold}$. After 3 weeks of incubation the DNA concentration decreased to $4360 \mathrm{ng} / \mathrm{g}$ wet weight $(68.1 \%)$ in the static group from the initial DNA concentration. Whereas in the group exposed to dynamic flow it decreased to $12720 \mathrm{ng} / \mathrm{g}$ wet weight $(7.0 \%)$ as shown in Figure 21 . The difference between the static and flow group is significantly different $(p<0.05)$ meaning less cells died when they were exposed to flow. 


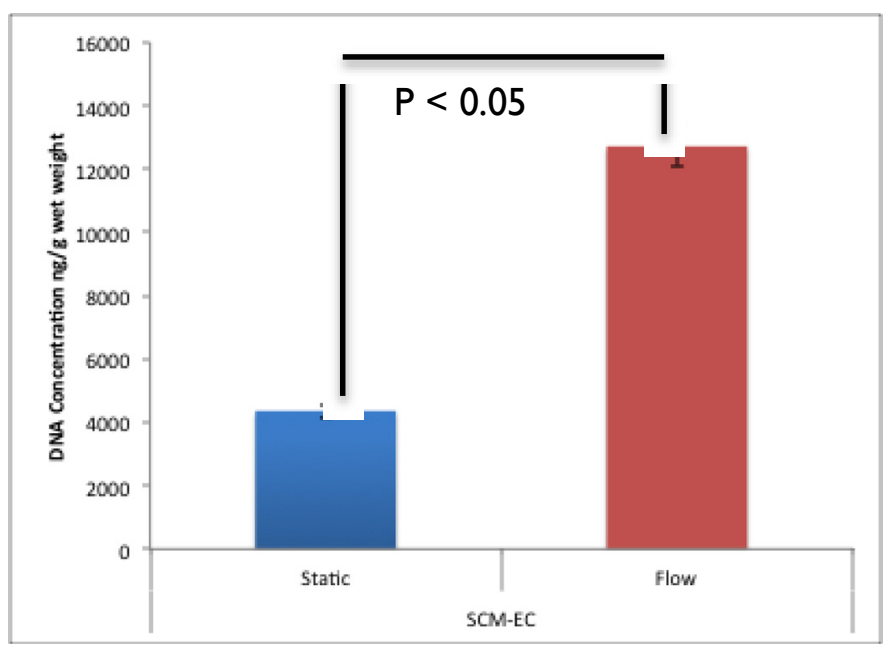

Figure 21: DNA content of SMC-EC seeded scaffolds after 3 weeks of incubation. Values presented are the mean of the measurements for 3 samples. Error bars indicate standard error.

\section{Extra Cellular Matrix Quantification for SMC-EC-seeded Scaffolds:}

After the 3 week period, the collagen concentration was $436.8 \pm 15.04 \mathrm{ug} / \mathrm{g}$ wet weight in the group exposed to flow compared with $218.9 \pm 25.9 \mathrm{ug} / \mathrm{g}$ wet weight in the static group. There was a $99.5 \%$ increase in collagen in the group exposed to flow compared to the static group $(p<0.05)$. On the other hand, the S-GAG concentration was $351.6 \pm 44.5 \mathrm{ug} / \mathrm{g}$ wet weight in the group exposed to flow, compared to $424.38 \pm 36.6 \mathrm{ug} / \mathrm{g}$ wet weight in the control group. This represents a $17.1 \%$ decrease in the GAG production from the scaffolds exposed to flow in comparison to the static controls (Figure 22), which is not significantly different. 


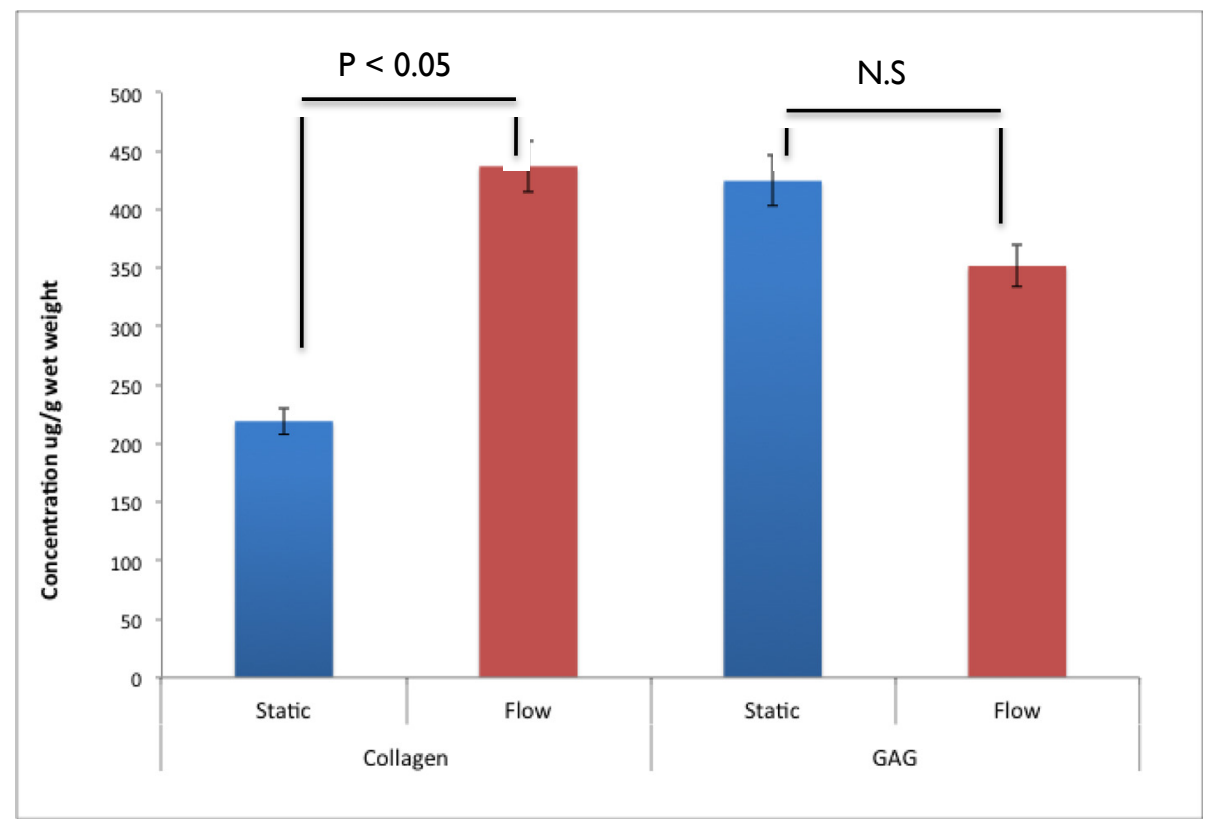

Figure 22: Composition content of SMC-EC seeded scaffolds after 3 weeks of incubation. Values presented are the mean of the measurements for 3 samples. Error bars indicate standard error. Insignificant comparisons are designated by "N.S.". The group exposed to flow exhibited a $99.5 \%$ increase in collagen compared to the static group $(p<0.05)(n=3)(r=5)$.

DNA Quantification for PDLSC-seeded Scaffolds: DNA was quantified in the same way as for the SMC-EC-seeded scaffolds. Similarly, a seeding density of $2 \times 10^{6}$ cells/scaffold was utilized, and $90 \%$ cell retention was assumed. Therefore based on the $7.6 \mathrm{pg}$ DNA content/cell (45), there was an average initial DNA content of $13.68 \mathrm{ug} / \mathrm{scaffold}$. 3 weeks post culture of the scaffold, the DNA concentration decreased to $4130 \mathrm{ng} / \mathrm{g}(69.8 \%)$ wet weight in the static group and decreased $8830 \mathrm{ng} / \mathrm{g}$ wet weight $(35.5 \%)$ in the group exposed to dynamic flow as shown on Figure 23. The difference between the static and flow group is significantly different $(p<0.05)$ meaning less cells died when they were exposed to flow. 


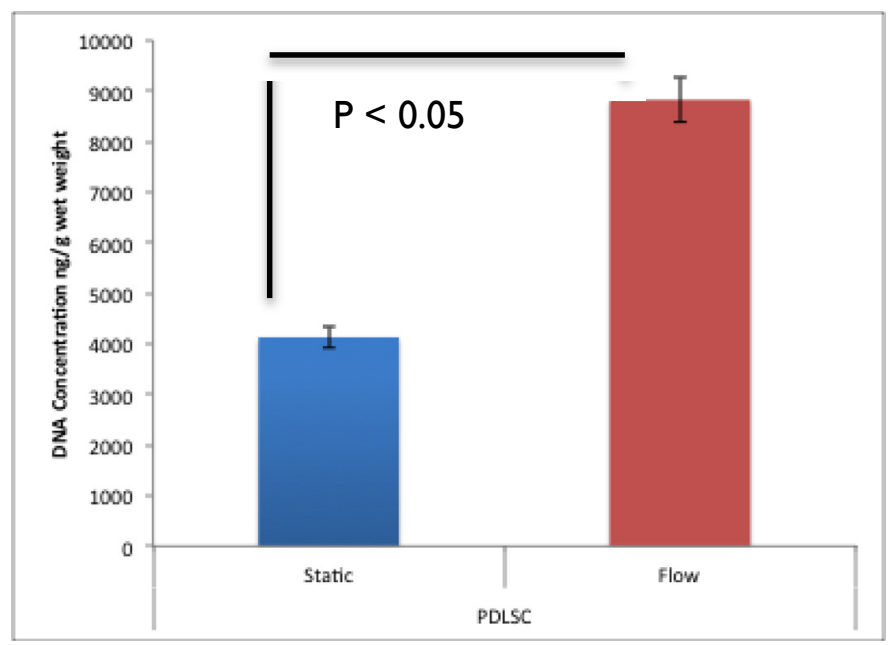

Figure 23: DNA content of PDLSC seeded scaffolds after 3 weeks of incubation. Values presented are the mean of the measurements for 3 samples. Error bars indicate standard error. $(n=3)(r=5)$.

\section{Extra Cellular Matrix Quantification for PDLSC-seeded Scaffolds:}

After the 3 week period, for the PDLSC-seeded scaffolds the collagen concentration was $400.2 \pm 13.2 \mathrm{ug} / \mathrm{g}$ wet weight in the group exposed to flow compared with $207.8 \pm 10.2 \mathrm{ug} / \mathrm{g}$ wet weight in the static group. There was a 93.3\% increase in collagen group exposed to flow compared to the static group $(p<0.05)$. Furthermore, the S-GAG concentration was $296.0 \pm 15.6 \mathrm{ug} / \mathrm{g}$ wet weight in the group exposed to flow, compared to $307.5 \pm 15.6 \mathrm{ug} / \mathrm{g}$ wet weight in the control group. This represents a $3.7 \%$ decrease in the GAG production from the scaffolds exposed to flow in comparison to the static controls, which is not significantly different (Figure 24). 


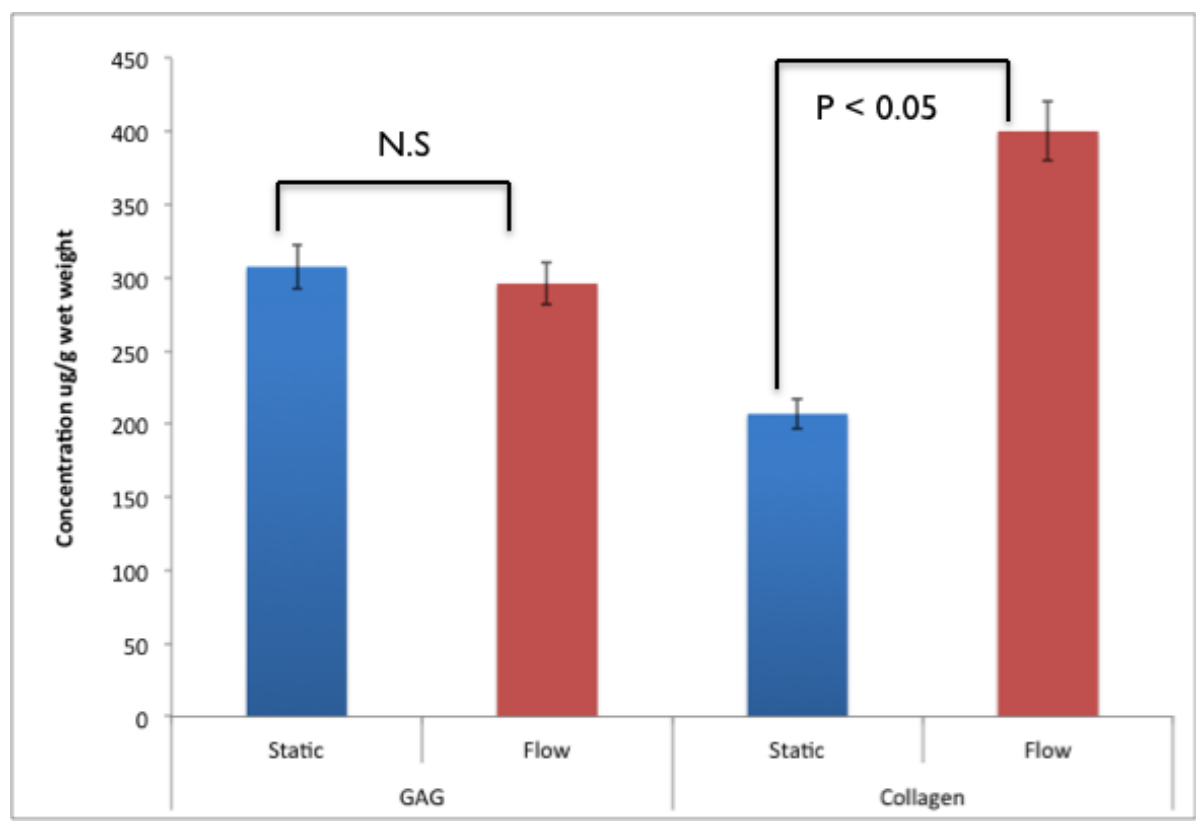

Figure 24: Composition content of PDLSC seeded scaffolds after 3 weeks of incubation. Values presented are the mean of the measurements for 3 samples. Error bars indicate standard error. Insignificant comparisons are designated by "N.S.". The group exposed to flow exhibited a $93.3 \%$ increase in collagen compared to the static group $(p<0.05) .(n=3)(r=5)$

Mechanical conditioning is believed to stimulate tissue formation in engineered tissues. It has been shown by researchers $(9,18-21)$ that mechanical properties of engineered heart valves can be improved through bioreactor-based mechanical stimulation. The u-shaped bioreactor utilized in our study has the potential to provide physiological hemodynamic conditions during in vitro tissue development while keeping laminar conditions as shown by precise steady state states which is an essential aspect for tissue formation. The effects of fluid shear stress on tissue formation can then be evaluated by bulk protein, differentiation capacity, mechanical properties and cell signaling events.

We were able to successfully image a 3D construct with ferumoxidelabeled PDLSCs under MRI, and further validate the presence of iron oxide 
indirectly via fluorescent microscopy. At the same time we showed the general distribution of the PDLSCs that were seeded onto a 50:50 PLLA/PGA blend of biodegradable scaffolds through H\&E staining. Thus, cell visualization on 3-D scaffolds specimens could be successfully carried out in situ in the U-shaped bioreactor, intermittently, during the steady flow-conditioning period. These findings demonstrate the ability to successfully conduct cell tracking studies on scaffolds that are undergoing a mechanical conditioning process in a longitudinal fashion, using MRI.

An intrinsic goal of TEPV efforts is to recapitulate native valve extra cellular matrix protein concentrations, namely, collagen, GAG and elastin. In our study we found that mechanical stimulation by means of a physiological relevant flow $(750 \mathrm{~mL} / \mathrm{min})$ augmented the collagen production in both EC-SMC and PDLSC seeded scaffolds after 3 weeks of culture $(1$ week static +2 week dynamic). SMC-EC seeded scaffolds were subjected to dynamic flow exhibiting increased collagen mass production levels compared to our static controls. Similarly, PDLSC seeded scaffolds exposed to dynamic flow also displayed higher collagen formation than non-flow cultured scaffolds. This represents a similar behavior in tissue formation by both SMC-EC and PDLSC seeded scaffolds. Also, consistent with other researchers $(1,5)$, we found a reduction in the GAG concentration when applying dynamic flow to the cell-seeded scaffolds. Flanagan et al and Balguid et al $(46,47)$ performed some studies on GAG production, finding that the integration of a GAG constituent to the scaffold causes enhanced extracellular matrix production. The accelerated collagen 
formation rates in the flow-groups may limit the cells ability to synthesize large concentrations of GAGs simultaneously. GAG concentrations in the TEPV constructs reflective of native valves may be reached by exogenous supplementation; alternatively, some level of initial static tissue culture may be necessary before initiating the dynamic conditioning protocols. In addition we did not examine elastin levels in our experiments. Thus, further investigations are needed in order to further optimize the tissue engineering protocol.

DNA content of both SMC-EC and PDLSC scaffolds was decreased after 3 weeks of culture on both static and dynamic groups. This would mean that less cells are retained in the tissue over time, however the ability of the cells to secrete more collagen increases with physiological flow conditioning.

For future studies, we would like to incorporate the flex and stretch features of the $u$ shaped bioreactor, and see how cyclic flexure affects tissue formation over a 3 week period.

\section{CONCLUSION}

In summary, we were able to detect spatial position of cells noninvasively using MRI. The cells (SMCs, ECs and PDLSCs) were efficiently labeled with SPIO microparticles at an optimum concentration of $200 \mu \mathrm{g} / \mathrm{mL}$ in combination with of transfection agents, protamine sulfate at a concentration of $4.5 \mu \mathrm{g} / \mathrm{mL}$ for vascular cells and $12 \mu \mathrm{g} / \mathrm{mL}$ for stem cells. The iron oxide presence inside the cells was confirmed by fluorescence microscopy (red tag). We expect that the 
cellular MRI techniques performed for the cell populations in this study will guide protocol optimization during in vitro to in vivo translation of TEPV constructs.

On a separate note, we found that PDLSCs subjected to differentiating media, and a shear stress of $1 \mathrm{dyne} / \mathrm{cm}^{2}$ induces differentiation to SMC and EC phenotypes. PDLSCs have the potential to become a single cell source feasible for the creation of tissue engineering pulmonary valves as they have the ability to support valve cell phenotypes (e.g. SMC s and ECs). They can be easily culture expanded and possess sufficient plasticity to remodel into valve tissue thus making them an appealing cell source for heart valve tissue engineering.

We studied the effects of mechanical stimulation by means of steady flow, by the use of our u-shaped bioreactor, in which we placed seeded SMC-EC and PDLSC seeded scaffolds and effectively obtained more robust collagen matrix production. Therefore, the study shows that both native cells (SMC-EC) and our viable cell source (PDLSC) both augmented levels of collagen production when stimulated by physiological levels of flow. Cellular scaffolds were also successfully visualized in situ in the u-shaped bioreactor and successfully validated by means of histology and fluorescence microscopy.

Significance: This project has an overall impact in the field of TEPVs. Specifically, it leads to a better understanding of the cell distribution of vascular cells and stem cells under static as well as steady flow states. Fluid shear stresses are one of the major physical stimulatory components of native heart valve and thus from a biomimetic viewpoint is relevant to heart valve tissue 
engineering studies. Also, we introduced PDLSC into the heart valve tissue engineering field; they were presented as a potential allogenic cell source for creating heart valve constructs by demonstrating concomitant differentiation into EC and SMC phenotypes. In particular, more complete EC differentiation was observed under combined biochemical and flow states. VE-CADHERIN was uniquely expressed under these conditions, which is indispensable for proper vascular development.

Future Work: We hope that future in vitro studies will include longitudinal MR imaging of SPIO-labeled cells (SMC-EC and PDLSC) seeded on PGA/PLLA to be able to understand further the migration of cells when exposed to flow conditions in the u-shaped bioreactor. These studies can be then compared to the findings from this project related to tissue formation, differentiative capacity, plus histological and fluorescent validation of the iron oxide presence inside the cells. In addition, other stress states such as pulsatile flow, cyclic flexure and dynamic tensile stresses individually or in a coupled manner, need to be further investigated. Nonetheless this work has taken the first steps in delineating the role of a fluid-induced stress state on cells relevant to engineered heart valve tissue engineering and forms the basis for further work that will examine the mechano-biology of evolving heart valve tissues. 


\section{REFERENCES}

1. Engelmayr Jr GC, Rabkin E, Sutherland FW, Schoen FJ, Mayer Jr JE, Sacks MS. The independent role of cyclic flexure in the early in vitro development of an engineered heart valve tissue. Biomaterials 2005;26(2):175-87.

2. Cannegieter SC, Rosendaal FR, Briet E. Thromboembolic and bleeding complications in patients with mechanical heart valve prostheses. Circulation 1994;89:635- 41.

3. Schoen, F. \& Levy, R. 1999 Tissue heart valves: current challenges and future research perspectives. J. Biomed. Mater. Res. 47, 439-465.

4. Mayer Jr. JE. Uses of homograft conduits for right ventricle to pulmonary artery connections in the neonatal period. Semin Thorac Cardiovasc Surg 1995;7(3):130-2.

5. Engelmayr Jr GC, Sales VL, Mayer Jr JE, Sacks MS. Cyclic flexure and laminar flow synergistically accelerate mesenchymal stem cell-mediated engineered tissue formation: implications for engineered heart valve tissues. Biomaterials 2006; 27(36):6083-95

6. Schoen, F. J. 2005 Cardiac valves and valvular pathology: update on function, disease, repair, and replacement. Cardiovasc. Pathol. 14, 189-194.

7. Schoen, F. J. 2006 New frontiers in the pathology and therapy of heart valve disease: 2006 Society for CardiovascularPathology. Distinguished Achievement Award Lecture, United States-Canadian Academy of Pathology, Atlanta, GA, February 12, 2006. Cardiovasc. Pathol. 15, 271-279.

8. Sutherland FW, Perry TE, Yu Y, Sherwood MC, Rabkin E, Masuda Y, et al. From stem cells to viable autologous semilunar heart valve. Circulation 2005; 111(21): 2783-91.

9. Hoerstrup SP, Sodian R, Daebritz S, Wang J, Bacha EA, Martin DP, et al. Functional living trileaflet heart valves grown in vitro. Circulation 2000;102(19 Suppl. 3): III44-9.

10. Ramaswamy S, Schornack PA, Smelko AG, Boronyak SM, Ivanova J, Mayer JE, Sacks MS: SPIO Labeling Efficiency and Subsequent MRI Tracking of Native Cell Populations Pertinent to Pulmonary Heart Valve Tissue Engineering Studies. NMR in Biomedicine, (In press).

11. Rabkin E, Schoen FJ. Cardiovascular tissue engineering. Cardi- ovasc Pathol 2002;11(6):305-17. 
12. Huang CY, Pelaez D, Dominguez-Bendala J, Garcia-Godoy F, Cheung HS. Plasticity of stem cells derived from adult periodontal ligament. Regen Med. 2009 Nov;4(6):809-21.

13. Boyer LA, Lee TI, Cole MF, Johnstone SE, Levine SS, Zucker JP, Guenther MG, Kumar, RM, Murray HL, Jeener RG, Gifford DK, Melton DA, Jaenisch R, Young, RA.

Core Transcriptional Regulatory Circuitry in Human Embryonic Stem Cells. Cell. 2005 September 23; 122(6): 947-956

14. Adewumi O, Aflatoonian $B$, Ahrlund-Richter L, Amit M, Andrews PW, Beighton G, Bello PA, Benvenisty N, Berry LS, Bevan S, Blum B, Brooking J,Chen KG, Choo AB, Churchill GA, Corbel M, Damjanov I, Draper JS, Dvorak $P$, Emanuelsson K, Fleck RA, Ford A, Gertow K, Gertsenstein M, Gokhale PJ, Hamilton RS, Hampl A, Healy LE, Hovatta O, Hyllner J, Imreh MP, ItskovitzEldor J, Jackson J, Johnson JL, Jones M, Kee K, King BL, Knowles BB, Lako M, Lebrin F, Mallon BS, Manning D, Mayshar Y,McKay RD, Michalska AE, Mikkola M, Mileikovsky M, Minger SL, Moore HD, Mummery CL, Nagy A, Nakatsuji N, O'Brien CM, Oh SK, Olsson C, Otonkoski T, Park KY, Passier R,Patel H, Patel M, Pedersen R, Pera MF, Piekarczyk MS, Pera RA, Reubinoff BE, Robins AJ, Rossant J, Rugg-Gunn P, Schulz TC, Semb H, Sherrer ES, Siemen H, Stacey GN,Stojkovic M, Suemori H, Szatkiewicz J, Turetsky T, Tuuri T, van den Brink S, Vintersten K, Vuoristo S, Ward D, Weaver TA, Young LA, Zhang W. Characterization of human embryonic stem cell lines by the International Stem Cell Initiative. Nat Biotechnol. 2007 Jul;25(7):803-16. Epub 2007 Jun 17.

15. Hutmacher DW, Goh JC, Teoh SH. An introduction to biodegradable materials for tissue engineering applications. Ann Acad Med Singapore 2001;30(2):183-91.

16. Hutmacher DW. Scaffold design and fabrication technologies for engineering tissues - state of the art and future perspectives. J Biomater Sci Polym Ed 2001;12(1):107-24.

17. Hoerstrup SP, Kadner A, Melnitchouk S, Trojan A, Eid K, Tracy J, et al. Tissue engineering of functional trileaflet heart valves from human marrow stromal cells. Circulation 2002;106(12 Suppl. 1):I143-50.

18. Engelmayr Jr GC, Sacks MS. Prediction of extracellular matrix stiffness in engineered heart valve tissues based on nonwoven scaffolds. Biomech Model Mechanobiol 2008;7(4):309-21.

19. Hoerstrup SP, Sodian R, Sperling JS, Vacanti JP, Mayer Jr JE. New pulsatile bioreactor for in vitro formation of tissue engineered heart valves. Tissue Eng 2000;6(1):75-9.

20. Stickler, P., et al. Cyclically stretching developing tissue in vivo enhances 
mechanical strength and organization of vascular grafts. Acta Biomaterialia, 2010: 6(7), 2448-2456.

21. Ramaswamy S, Boronyak S, Schmidt D, Sacks MS:Design and Evaluation of a New Flow-Stretch-Flexure Bioreactor for Mechanical Conditioning of Engineered Heart Valve Tissues in the Physiological Range. The TERMIS-NA 2008 Annual Conference \& Exposition, San Diego, CA, December 7 - 10, 2008.

22. Hill JM, Dick AJ, Raman VK, Thompson RB, Yu ZX, Hinds KA, Pessanha BS, Guttman MA, Varney TR, Martin BJ, Dunbar CE, McVeigh ER, Lederman RJ. Serial cardiac magnetic resonance imaging of injected mesenchymal stem cells. Circulation 2003;108(8):1009-1014.

23. Gottlieb D, Kunal T, Emani S, Aikawa E, Brown DW, Powell AJ, Nedder A, Engelmayr GC, Jr., Melero-Martin JM, Sacks MS, Mayer JE, Jr. In vivo monitoring of function of autologous engineered pulmonary valve. J Thorac Cardiovasc Surg; 139(3):723-731.

24. Sosnovik DE . Molecular Imaging in Cardiovascular Magnetic Resonance Imaging: Current Perspective and Future Potential Top Magn Reson Imaging. 2008 February ; 19(1): 59-68

25. Ramaswamy S, Greco JB, Uluer MC, Zhang Z, Fishbein KW, Spencer RG. Magnetic resonance imaging of chondrocytes labeled with superparamagnetic iron oxide nanoparticles in tissue-engineered cartilage. Tissue Eng Part A 2009;15(12):3899-3910.

26. Terrovitis JV, Bulte JW, Sarvananthan S, Crowe LA, Sarathchandra P, Batten P, Sachlos E, Chester AH, Czernuszka JT, Firmin DN, Taylor PM, Yacoub $\mathrm{MH}$. Magnetic resonance imaging of ferumoxide-labeled mesenchymal stem cells seeded on collagen scaffolds-relevance to tissue engineering. Tissue Eng 2006;12(10):2765-2775

27. Arbab AS, Yocum GT, Rad AM, Khakoo AY, Fellowes V, Read EJ, Frank JA. Labeling of cells with ferumoxides-protamine sulfate complexes does not inhibit function or differentiation capacity of hematopoietic or mesenchymal stem cells.NMR Biomed. 2005;18:383-389

28. Arbab AS, Frank JA. Cellular MRI and its role in stem cell therapy. Regen Med 2008;3(2):199-215.

29. Ko IK, Song HT, Cho EJ, Lee ES, Huh YM, Suh JS. In vivo MR imaging of tissue-engineered human mesenchymal stem cells transplanted to mouse: a preliminary study. Annals of biomedical engineering 2007;35(1):101-108.

30. Frangioni JV, Hajjar RJ. In vivo tracking of stem cells for clinical trials in cardiovascular disease. Circulation 2004;110(21):3378-3383 
31. Suzuki Y, Zhang S, Kundu P, Yeung AC, Robbins RC, Yang PC. In Vitro Comparison of the Biological Effects of Three Transfection Methods for Magnetically Labeling Mouse Embryonic Stem Cells With Ferumoxides. Magnetic Resonance in Medicine 57:1173-1179 (2007)

32. Pelaez, D. Role of Mechanical Strain on the Cardiomyogenic Differentation of Periodontal Ligament Derived Stem Cells". A Dissertation at the University of Miami. May 2011

33. Wang T, Xu Z, Jiang W, Ma A. Cell-to-cell contact induces mesenchymal stem cell to differentiate into cardiomyocyte and smooth muscle cell. Int J Cardiol. 2006 Apr 28;109(1):74-81

34. Li X, Yu X, Lin Q, Deng C, Shan Z, Yang M, Lin S. Bone marrow mesenchymal stem cells differentiate into functional cardiac phenotypes by cardiac microenvironment. J Mol Cell Cardiol. 2007 Feb;42(2):295-303.

35. Ramaswamy S, Gottlieb D, Engelmayr GC Jr, Aikawa E, Schmidt DE, Gaitan-Leon DM, Sales VL, Mayer JE Jr, Sacks MS. The role of organ level conditioning on the promotion of engineered heart valve tissue development invitro using mesenchymal stem cells.Biomaterials 31 (2010) 1114-1125

36. Martinez C, Padgett K, Henao A, Ramaswamy S. Migration of Vascular Cells Exposed to Valve-Like Deformations: Implications for Heart Valve Tissue Engineering. TERMIS Conference Meeting, Orlando, FL, December 2010.

37. Martinez C, Padgett K, Henao A, Pelaez D, Ramaswamy S. Iron Oxide Labeling of Three Different Cell Populations: Relevant to Tissue Engineered Heart Valves. BMES Conference Meeting, Hartford,CN, October 2011.

38. Vandesompele J, De Preter K, Pattyn F, Poppe B, Van Roy N, De Paepe A, Speleman F. Accurate normalization of real-time quantitative RT-PCR data by geometric averaging of multiple internal control genes. Genome Biol. 2002 Jun 18;3(7):RESEARCH0034.

39. Cahill KS, Gaidosh G, Huard J, et al. Noninvasive Monitoring and Tracking of Muscle Stem Cell Transplants. Transplantation 2004;78:1626-33.

40. Rogers WJ, Meyer $\mathrm{CH}$, Kramer $\mathrm{CM}$. Technology insight: in vivo cell tracking by use of MRI. Nat Clin Pract Cardiovasc Med 2006; 3: 554-62.

41. Zhang N, Mascheri N, Dharmakumar R, Li D. Cellular Magnetic Resonance Imaging: Potential for Use in Assessing Aspects of Cardiovascular Disease. Cytotherapy. 2008 ; 10(6): 575-586.

42. Harrington JK, Chahboune $\mathrm{H}$, Criscione JM, Li AY, Hibino N, Yi T, Villalona GA, Kobsa S, Meijas D, Duncan DR, Devine L, Papademetri X, Shin'oka T, 
Fahmy TM, Breuer CK. Determining the fate of seeded cells in venous tissueengineered vascular grafts using serial MRI. FASEB J. 2011 Aug 16.

43. Zhang $\mathbf{G}$ et al. A PEGylated Fibrin Patch for Mesenchymal Stem Cell Delivery. Tissue Eng 2006;12(1):9-19.

44. Zhang $\mathbf{G}$ et al . Vascular differentiation of bone marrow stem cells is directed by a tunable three-dimensional matrix Acta Biomaterialia 6 (2010) 3395-3403

45. Kim BS, Putnam AJ, Kulik TJ, Mooney DJ. Optimizing seeding and culture methods to engineer smooth muscle tissue on biodegradable polymer matrices. Biotechnol Bioeng 1998;57(1): 46-54.

46. Flanagan TC, Wilkins B, Black A, Jockenhoevel S, Smith TJ, Pandit AS. A collagen-glycosaminoglycan co-culture model for heart valve tissue engi- neering applications. Biomaterials 2006;27(10):2233-46.

47.Balguid A, Mol A, van Vlimmeren MA, Baaijens FP, Bouten CV. Hypoxia induces near-native mechanical properties in engineered heart valve tissue. Circula- tion 2009;119(2):290-7. 